\title{
Article \\ Cyclosporine A and Tacrolimus Induce Functional Impairment and Inflammatory Reactions in Endothelial Progenitor Cells
}

\author{
Nadia Meyer ${ }^{1}$, Lars Brodowski ${ }^{1,2}$, Constantin von Kaisenberg ${ }^{2}$, Bianca Schröder-Heurich ${ }^{1,+}$ \\ and Frauke von Versen-Höynck $1,2, *,+$ (D) \\ 1 Gynecology Research Unit, Hannover Medical School, Carl-Neuberg-Strasse 1, D-30625 Hannover, Germany; \\ Meyer.Nadia@mh-hannover.de (N.M.); Brodowski.Lars@mh-hannover.de (L.B.); \\ Schroeder-Heurich.Bianca@mh-hannover.de (B.S.-H.) \\ 2 Department of Obstetrics and Gynecology, Hannover Medical School, Carl-Neuberg-Strasse 1, \\ D-30625 Hannover, Germany; vonKaisenberg.Constantin@mh-hannover.de \\ * Correspondence: vonVersen-Hoeynck.Frauke@mh-hannover.de \\ + Shared last authorship.
}

Citation: Meyer, N.; Brodowski, L.; von Kaisenberg, C.;

Schröder-Heurich, B.; von

Versen-Höynck, F. Cyclosporine A and Tacrolimus Induce Functional Impairment and Inflammatory

Reactions in Endothelial Progenitor Cells. Int. J. Mol. Sci. 2021, 22, 9696. https://doi.org/10.3390/ijms22189696

Academic Editors: Jolanta Weaver, Germano Guerra and

Francesco Moccia

Received: 29 July 2021

Accepted: 3 September 2021

Published: 8 September 2021

Publisher's Note: MDPI stays neutral with regard to jurisdictional claims in published maps and institutional affiliations.

Copyright: (c) 2021 by the authors. Licensee MDPI, Basel, Switzerland. This article is an open access article distributed under the terms and conditions of the Creative Commons Attribution (CC BY) license (https:/ / creativecommons.org/licenses/by/ $4.0 /)$.

\begin{abstract}
Immunosuppressants are a mandatory therapy for transplant patients to avoid rejection of the transplanted organ by the immune system. However, there are several known side effects, including alterations of the vasculature, which involve a higher occurrence of cardiovascular events. While the effects of the commonly applied immunosuppressive drugs cyclosporine A (CsA) and tacrolimus (Tac) on mature endothelial cells have been addressed in several studies, we focused our research on the unexplored effects of CsA and Tac on endothelial colony-forming cells (ECFCs), a subgroup of endothelial progenitor cells, which play an important role in vascular repair and angiogenesis. We hypothesized that CsA and Tac induce functional defects and activate an inflammatory cascade via NF- $k B$ signaling in ECFCs. ECFCs were incubated with different doses $(0.01 \mu \mathrm{M}-10 \mu \mathrm{M})$ of CsA or Tac. ECFC function was determined using in vitro models. The expression of inflammatory cytokines and adhesion molecules was explored by quantitative real-time PCR and flow cytometry. NF- $\kappa B$ subunit modification was assessed by immunoblot and immunofluorescence. CsA and Tac significantly impaired ECFC function, including proliferation, migration, and tube formation. TNF- $\alpha$, IL-6, VCAM, and ICAM mRNA expression, as well as PECAM and VCAM surface expression, were enhanced. Furthermore, CsA and Tac led to NF- $\mathrm{B}$ p 65 subunit phosphorylation and nuclear translocation. Pharmacological inhibition of NF-kB by parthenolide diminished CsA- and Tac-mediated proinflammatory effects. The data of functional impairment and activation of inflammatory signals provide new insight into mechanisms associated with CsA and Tac and cardiovascular risk in transplant patients.
\end{abstract}

Keywords: endothelial colony-forming cells; endothelial progenitor cells; cyclosporine A; tacrolimus; endothelial dysfunction; cardiovascular risk; inflammation; transplantation

\section{Introduction}

Immunosuppressant use is common in autoimmune, rheumatological, and chronic inflammatory bowel diseases, while their application is mandatory to prevent rejection after organ transplantation [1]. Frequently used immunosuppressants are cyclosporine A and tacrolimus. They prevent the activation of the phosphatase calcineurin. As a consequence, the nuclear factor of activated T cells cannot be dephosphorylated and translocated into the cell nucleus. As a result, $\mathrm{T}$ cell activation, transcription, and release of cytokines such as IL-2 are inhibited [2].

In addition to the intended mechanism, there are numerous side effects associated with their use. Endothelial dysfunction is one of the most recognized vascular impacts in patients after organ transplantation and is associated with nephrotoxicity, hypertension, hypercholesterinemia, and hyperglycemia [3,4]. 
While the impact of cyclosporine A and tacrolimus on mature endothelial cells has been addressed by different studies [5,6], it is barely known whether the functionality of endothelial progenitor cells (EPCs) is affected by them. Asahara et al. described and isolated EPCs for the first time in 1997 [7]. EPCs are impaired in several cardiovascular diseases [8-10] and considered a strong biomarker to determine endothelial dysfunction and cardiovascular risk [11-14]. Endothelial colony-forming cells (ECFCs), a subgroup of EPCs, are known for their high proliferative ability and play a crucial role in vascular repair and angiogenesis $[15,16]$. They contribute to endothelial integrity by incorporating into damaged vessel walls and further through paracrine effects $[17,18]$. At present, they are considered the most potent vascular reparative cell type among EPC subtypes [19].

A potent proangiogenic factor that regulates vascular growth and angiogenesis in EPCs is the vascular endothelial growth factor (VEGF). VEGF mediates its potentiating effect via AKT [20], a serine/threonine protein kinase that acts as a multifunctional intracellular regulator of cell growth, metabolism, and survival [21].

Inflammation is a hallmark of several diseases, e.g., cardiovascular disease [22] or preeclampsia [23], and is associated with higher cardiovascular risk in later life [24]. The activation of the protein complex nuclear factor kappa-light-chain-enhancer of activated $\mathrm{B}$ cells (NF- $\mathrm{kB}$ ) is crucial for the regulation of the immune response and is involved in the moderation of inflammatory responses in the cardiovascular system $[25,26]$. NF- $k B$ stimulates the transcription of proinflammatory cytokines, including tumor necrosis factor-alpha (TNF- $\alpha$ ) and interleukin 6 (IL-6) $[27,28]$. Nuclear translocation of the NF-kB p65 subunit is a key event in NF- $\mathrm{KB}$ activation [29]. Furthermore, NF- $\mathrm{kB}$ coordinates the expression of adhesion molecules, including vascular cell adhesion protein (VCAM), intercellular adhesion molecule (ICAM), and platelet and endothelial cell adhesion molecule (PECAM), which are important regulators of leukocyte extravasation, vascular permeability, and inflammatory processes $[28,30]$. Whereas in T lymphocytes, cyclosporine A and tacrolimus reduce the activation of NF- $\mathrm{kB}$ [31], they have opposite effects in renal tubular cells [32] and in murine pancreatic islet endothelial cells [33]. Whether a similar NF- $\mathrm{kB}$ modification causing inflammation may happen in ECFCs exposed to cyclosporine A or tacrolimus has not been addressed yet.

In light of the increased cardiovascular risk of transplant patients and ECFCs' key role in vascular repair and homeostasis, in this study, we investigate the effects of cyclosporine A and tacrolimus on the functional properties of ECFCs and on inflammatory cascades.

\section{Results}

\subsection{High-Dose Cyclosporine A and Tacrolimus Inhibit ECFC Proliferation}

Regarding one of their main characteristics, we analyzed ECFCs' proliferation in the presence or absence of different doses of cyclosporine A or tacrolimus. The cell index was continuously monitored with the xCelligence technology. Treatment with $0.01 \mu \mathrm{M}$ or $0.1 \mu \mathrm{M}$ cyclosporine A or tacrolimus did not affect ECFCs' proliferation, whereas treatment with $1 \mu \mathrm{M}$ or $10 \mu \mathrm{M}$ significantly decreased ECFCs' proliferation after $24 \mathrm{~h}$, $48 \mathrm{~h}$, and $72 \mathrm{~h}$, respectively (Figure 1A,B, Supplemental Tables S1-S3). Less pronounced but comparable effects were also observed at shorter exposures of $14 \mathrm{~h}$ and $18 \mathrm{~h}$, time points which were used in the migration and angiogenesis assays (Supplemental Figure S1, Supplemental Tables S4 and S5).

To explore whether apoptosis is involved in functional impairments observed after treatment with different doses of cyclosporine A or tacrolimus, we determined the expression level of the apoptosis marker annexin V using flow cytometry. After $48 \mathrm{~h}$ of incubation, there was no significant difference in apoptosis or necrosis in ECFCs treated with cyclosporine A or tacrolimus compared to vehicle control (Figure 1C,D, Supplemental Tables S6-S8). 
A

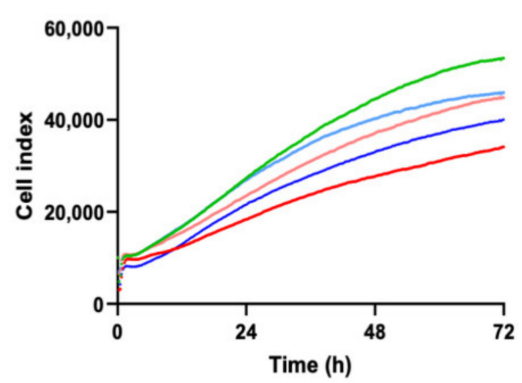

C
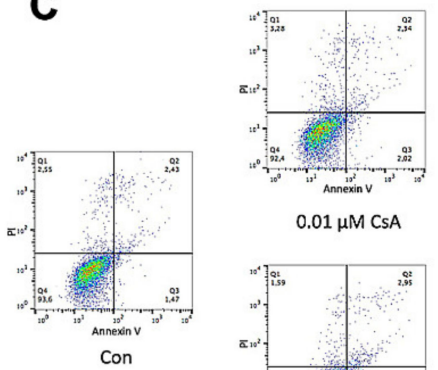

$0.01 \mu \mathrm{M}$ CsA

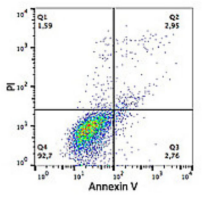

$0.01 \mu \mathrm{M}$ Tac

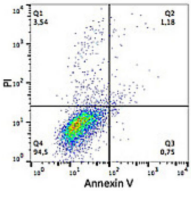

$0.1 \mu \mathrm{M}$ CsA

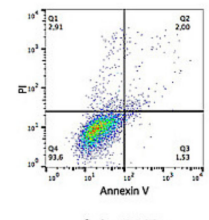

- Con

- $1 \mu \mathrm{M}$ CsA

- $10 \mu \mathrm{M}$ CsA

- $1 \mu \mathrm{M} \mathrm{Tac}$

- $10 \mu \mathrm{M}$ Tac
B

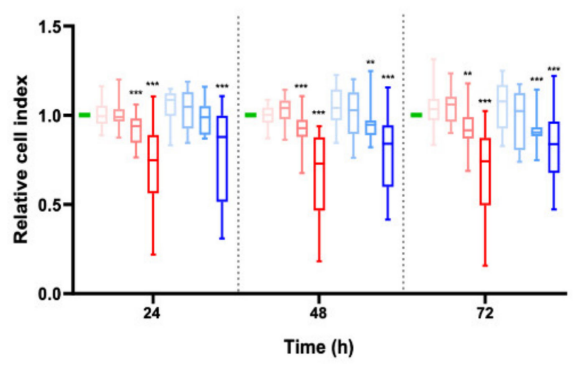

$\square$ Con

$0.01 \mu \mathrm{M} \mathrm{CsA}$

$\square 0.1 \mu \mathrm{M}$ CsA

$\square 1 \mu \mathrm{M}$ CsA

$\square 10 \mu \mathrm{M}$ CsA

$0.01 \mu \mathrm{M} \mathrm{Tac}$

$\square 0.1 \mu \mathrm{M} \mathrm{Tac}$

$\square 1 \mu \mathrm{M} \mathrm{Tac}$

口 $10 \mu \mathrm{M} \mathrm{Tac}$

Figure 1. High-dose cyclosporine A (CsA) and tacrolimus (Tac) impaired ECFC proliferation. (A) Overlay of growth curves of ECFCs treated with CsA or Tac $(1 \mu \mathrm{M}$ or $10 \mu \mathrm{M})$. (B) ECFC proliferation was not affected after treatment with 0.01 or $0.1 \mu \mathrm{M}$ CsA or Tac, but it was significantly decreased after treatment with $1 \mu \mathrm{M}$ or $10 \mu \mathrm{M}$ CsA or Tac after $24 \mathrm{~h}, 48 \mathrm{~h}$, and 72 h. $n=13-27$; control group set as 1. (C) Representative measurement of apoptosis and necrosis in ECFCs after $48 \mathrm{~h}$ treatment with CsA or Tac at $0.01 \mu \mathrm{M}, 0.1 \mu \mathrm{M}, 1 \mu \mathrm{M}$, or $10 \mu \mathrm{M}$. Viable cells are located in the lower left field (Annexin V neg./PI neg). (D) There was no significant increase of apoptotic or necrotic cells. $n=5$. Con—control; CsA—cyclosporine A; Tac-tacrolimus. ${ }^{* *} p<0.01,{ }^{* * *} p<0.001$.

\subsection{Cyclosporine A and Tacrolimus Impair ECFC Migration}

The directional migration of single cells is driven by a chemotactic gradient and was tested using a modified Boyden chamber assay. The chemotaxis ability of ECFCs was significantly lower when treated with cyclosporine A (relative number of migrated cells: $0.01 \mu \mathrm{M}: 0.83, p=0.02 ; 0.1 \mu \mathrm{M}: 0.80, p<0.001 ; 1 \mu \mathrm{M}: 0.74, p<0.001 ; 10 \mu \mathrm{M}: 0.72, p<0.001)$ or tacrolimus (relative number of migrated cells: $0.01 \mu \mathrm{M}: 0.77, p=0.02 ; 0.1 \mu \mathrm{M}: 0.80, p<0.001$; $1 \mu \mathrm{M}: 0.76, p<0.001 ; 10 \mu \mathrm{M}: 0.82, p<0.001$ ) (Figure 2A,B, Supplemental Table S9).

As cyclosporine $\mathrm{A}$ and tacrolimus have been shown to decrease the directional migration of ECFCs towards a chemoattractant, we further addressed if they also influence ECFCs' remigration of a scratch wound in a former monolayer. Wound closure was significantly lower in the presence of cyclosporine A (relative remigrated area: $0.01 \mu \mathrm{M}: 0.76$; $0.1 \mu \mathrm{M}: 0.75 ; 1 \mu \mathrm{M}: 0.71 ; 10 \mu \mathrm{M}: 0.40$, all $p<0.001$ ) and tacrolimus (relative remigrated area: $0.01 \mu \mathrm{M}: 0.81, p=0.003 ; 0.1 \mu \mathrm{M}: 0.80, p=0.002 ; 1 \mu \mathrm{M}: 0.77, p=0.002 ; 10 \mu \mathrm{M}: 0.78, p<0.001)$ (Figure 2C, Supplemental Figure S2, Supplemental Table S10).

To exclude cytotoxicity as the cause of the detected functional impairment, we performed an LDH assay with the supernatants of the scratch wound healing assay. There was no significant increase of LDH release after $18 \mathrm{~h}$ of incubation with 1 or $10 \mu \mathrm{M}$ cyclosporine A or tacrolimus compared to vehicle control (Con: $25.78 \% ; 1 \mu \mathrm{M}$ cyclosporine A: $27.96 \%$, $p=0.73 ; 10 \mu \mathrm{M}$ cyclosporine A: $38.43 \%, p=0.61 ; 1 \mu \mathrm{M}$ tacrolimus: $28.94 \%, p=0.73 ; 10 \mu \mathrm{M}$ tacrolimus: $31.22 \%, p=0.08$ ). All values were related to the positive control (Figure 2D, Supplemental Table S11). 


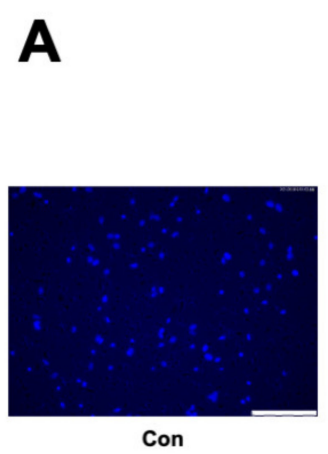

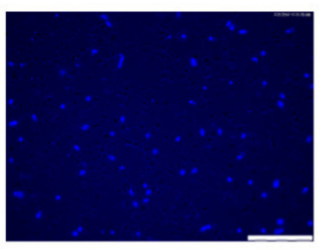

$0.01 \mu \mathrm{M}$ CsA

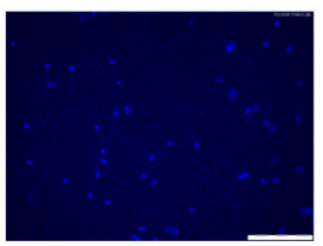

$0.01 \mu \mathrm{M} \mathrm{Tac}$

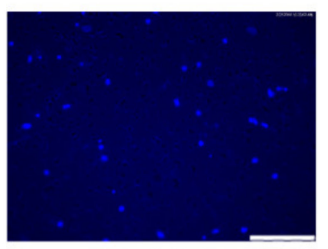

$0.1 \mu \mathrm{M}$ CsA

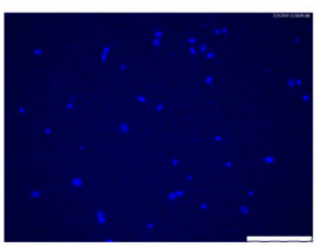

$0.1 \mu \mathrm{M}$ Tac

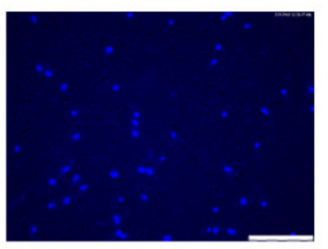

$1 \mu \mathrm{M}$ CsA

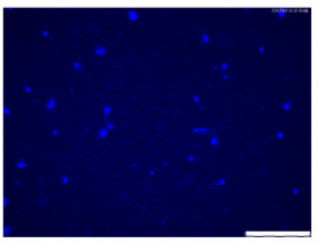

$1 \mu \mathrm{M} \mathrm{Tac}$

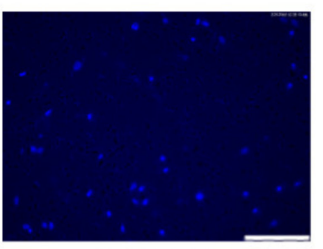

$10 \mu \mathrm{M}$ CsA

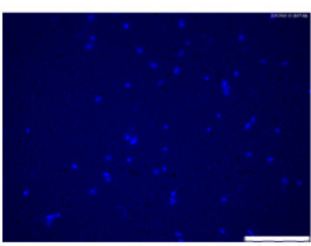

$10 \mu \mathrm{M} \mathrm{Tac}$
B

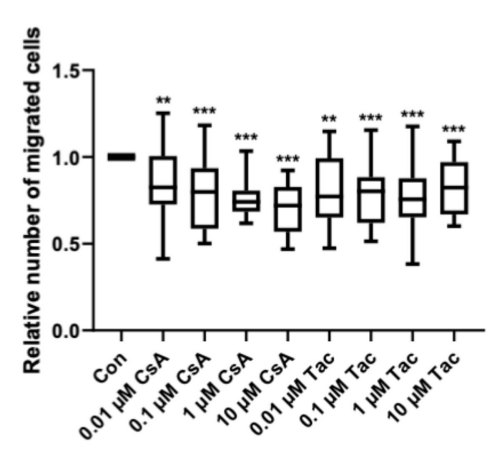

C

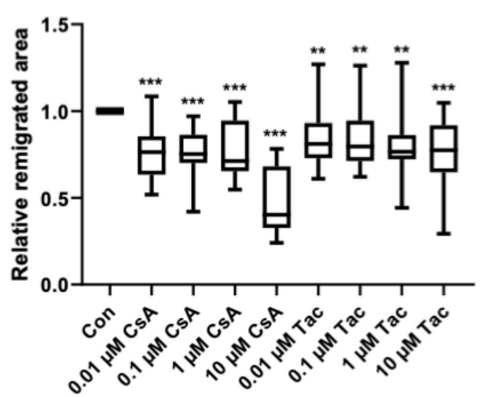

D

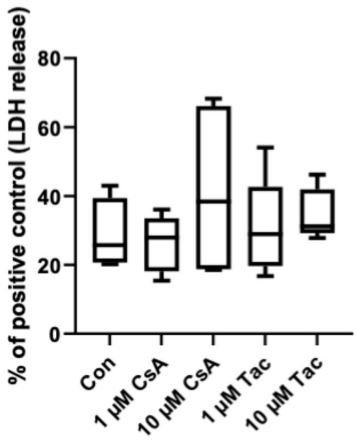

Figure 2. Cyclosporine A (CsA) and tacrolimus (Tac) impaired ECFC migration. (A) Representative images of DAPI-stained migrated ECFCs treated with CsA or Tac $(0.01-10 \mu \mathrm{M})$ in a chemotaxis assay, scale bar $150 \mu \mathrm{m}$. (B) ECFCs showed a significantly lower directional migration in presence of CsA or Tac after $4 \mathrm{~h}$. Numbers of DAPI-stained migrated cells on the bottom side of the membranes were counted in each picture, control group set as 1. $n=20$. (C) CsA or Tac treatment (0.01-10 $\mu \mathrm{M})$ of ECFCs diminished wound closure assessed as remigrated area after $18 \mathrm{~h}$ compared to control, control group set as 1. Representative images can be found in Supplemental Figure S2. $n=15-16$. (D) CsA or Tac $(1 \mu \mathrm{M}$ or $10 \mu \mathrm{M})$ did not lead to significantly higher LDH release after $18 \mathrm{~h}$, positive control set as $100 \%, n=9$. Con-control; CsA—cyclosporine A; Tac-tacrolimus. ${ }^{* *} p<0.01,{ }^{* * *} p<0.001$.

\subsection{Cyclosporine A and Tacrolimus Decrease ECFC Angiogenic Capacity and AKT Phosphorylation}

Reflecting ECFCs' ability of de novo vessel formation in vivo, we performed an in vitro angiogenesis assay to determine cyclosporine $\mathrm{A}$ and tacrolimus effects in presence of VEGF on ECFCs' ability to form capillary-like structures in Matrigel. After treatment with cyclosporine A or tacrolimus, ECFCs showed significantly shorter tube length than controls (cyclosporine A: $0.01 \mu \mathrm{M}: 0.77, p=0.005 ; 0.1 \mu \mathrm{M}: 0.67, p<0.001 ; 1 \mu \mathrm{M}: 0.57$, $p<0.001 ; 10 \mu \mathrm{M}: 0.47, p<0.001$; tacrolimus: $0.01 \mu \mathrm{M}: 0.79, p=0.02 ; 0.1 \mu \mathrm{M}: 0.72, p<0.001$; $1 \mu \mathrm{M}: 0.68, p<0.001 ; 10 \mu \mathrm{M}: 0.47, p<0.001$ ) (Figure 3A,B, Supplemental Table S12).

As AKT belongs to the main targets of VEGF and the AKT-cascade is considered an important signaling pathway in endothelial cells, we addressed possible effects of cyclosporine A and tacrolimus on AKT phosphorylation in ECFCs. Cyclosporine A $(1 \mu \mathrm{M})$ and tacrolimus (1 or $10 \mu \mathrm{M})$ reduced AKT phosphorylation after VEGF stimulation compared to control (cyclosporine A: $1 \mu \mathrm{M}: 0.76, p=0.04 ; 10 \mu \mathrm{M}: 0.95, p=0.27$; tacrolimus: $1 \mu \mathrm{M}:$ 0.70, $p=0.03 ; 10 \mu \mathrm{M} .0 .78, p=0.01$ ) (Figure 3C,D, Supplemental Table S13). 


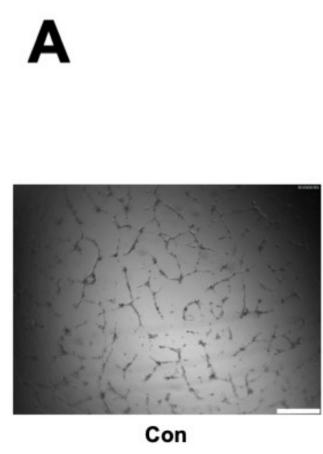

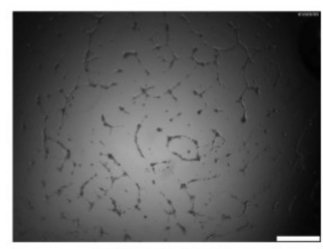

$0.01 \mu \mathrm{M}$ CsA

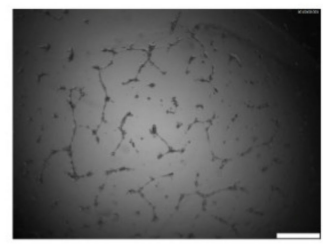

$0.01 \mu \mathrm{M} \mathrm{Tac}$

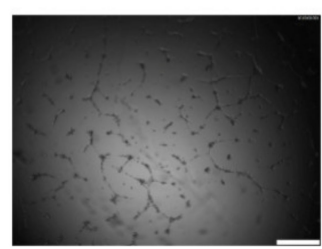

$0.1 \mu \mathrm{M}$ CsA

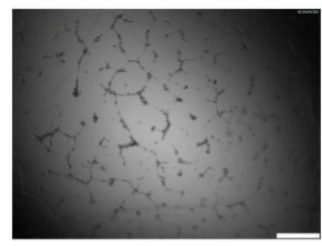

$0.1 \mu \mathrm{M}$ Tac

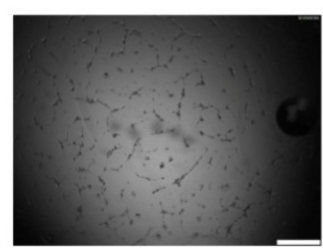

$1 \mu \mathrm{M}$ CsA

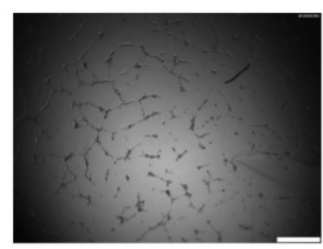

$1 \mu \mathrm{M} \mathrm{Tac}$

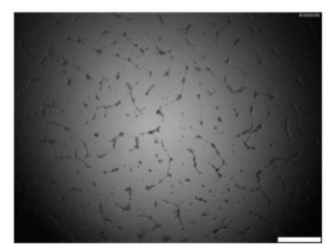

$10 \mu \mathrm{M}$ CsA

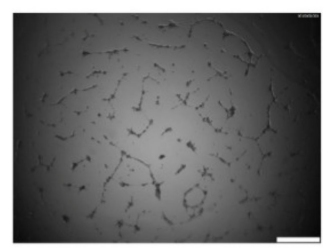

$10 \mu \mathrm{M} \mathrm{Tac}$
B

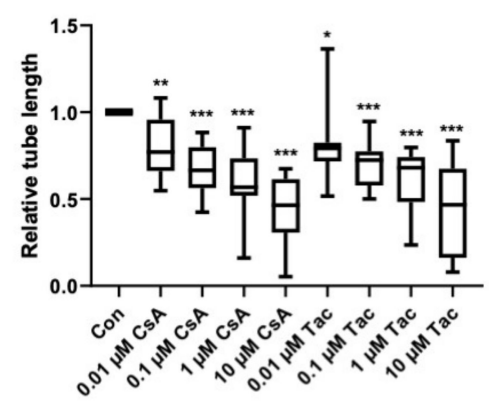

C

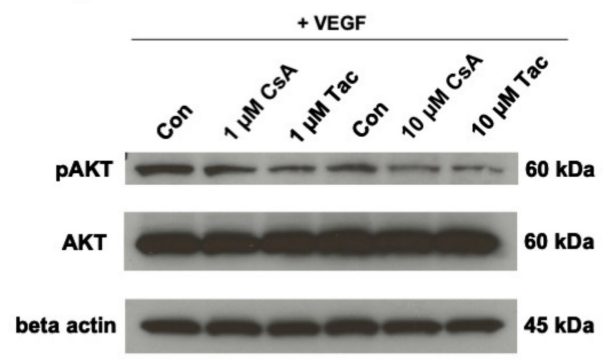

D

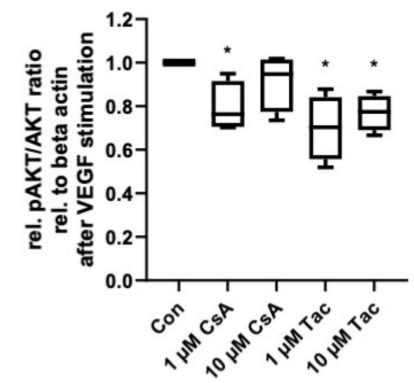

Figure 3. Cyclosporine A (CsA) and tacrolimus (Tac) impaired ECFC angiogenesis in presence of VEGF and reduced AKT phosphorylation. (A) Representative images from ECFCs treated with vehicle control only, $0.01 \mu \mathrm{M}$ CsA, $0.1 \mu \mathrm{M}$ CsA, $1 \mu \mathrm{M}$ CsA, $10 \mu \mathrm{M}$ CsA, $0.01 \mu \mathrm{M}$ Tac, $0.1 \mu \mathrm{M}$ Tac, $1 \mu \mathrm{M}$ Tac, $10 \mu \mathrm{M}$ Tac for $14 \mathrm{~h}$, scale bar $500 \mu \mathrm{m}$. (B) CsA and Tac treatment of ECFCs significantly decreased tube length after $14 \mathrm{~h}$ of incubation. Control group set as $1 . n=12$. (C) Representative immunoblot of AKT phosphorylation in the presence of CsA or Tac (1 or $10 \mu \mathrm{M})$ after 10 min of stimulation with VEGF. (D) CsA and Tac $(1$ or $10 \mu \mathrm{M})$ prevented the VEGF-induced AKT phosphorylation in ECFCs. Control group set as $1 . n=4$. Con—control; CsA—cyclosporine A; Tac—tacrolimus. ${ }^{*}, p<0.05,{ }^{* *} p<0.01,{ }^{* * *} p<0.001$.

\subsection{Cyclosporine A and Tacrolimus Affect Expression of Inflammatory Cytokines and} Adhesion Molecules

To explore the inflammatory reactions in ECFCs, we determined the mRNA levels of the inflammatory cytokines TNF- $\alpha$ and IL-6, as well as VCAM and ICAM mRNA levels, as markers of adhesion molecules under inflammatory conditions, by using qRT-PCR after $6 \mathrm{~h}$ of treatment with cyclosporine A or tacrolimus. ECFCs treated with cyclosporine A or tacrolimus ( 1 or $10 \mu \mathrm{M})$ showed a higher expression level of TNF- $\alpha$ (cyclosporine A: $1 \mu \mathrm{M}: 1.63, p=0.03 ; 10 \mu \mathrm{M}: 2.94, p=0.01$; tacrolimus: $1 \mu \mathrm{M}: 1.85, p=0.03 ; 10 \mu \mathrm{M}: 2.00$, $p=0.03$ ) and IL-6 (cyclosporine A: $1 \mu \mathrm{M}: 1.67, p=0.03 ; 10 \mu \mathrm{M}: 1.56, p=0.02$; tacrolimus: $1 \mu \mathrm{M}: 2.37, p=0.03 ; 10 \mu \mathrm{M}: 1.65, p=0.03$ ) compared to controls. The addition of the NF- $\mathrm{kB}$ inhibitor parthenolide attenuated the effect (Figure 4A, Supplemental Tables S14 and S15). Furthermore, treatment with cyclosporine A or tacrolimus led to a higher mRNA expression level of the adhesion molecules VCAM (cyclosporine A: $1 \mu \mathrm{M}: 2.13, p=0.02 ; 10 \mu \mathrm{M}: 2.09$, $p=0.01$; tacrolimus: $1 \mu \mathrm{M}: 2.39, p=0.03 ; 10 \mu \mathrm{M}: 2.11, p=0.04$ ) and ICAM (cyclosporine A: $1 \mu \mathrm{M}: 1.44, p=0.02 ; 10 \mu \mathrm{M}: 2.60, p=0.02$; tacrolimus: $1 \mu \mathrm{M}: 1.90, p=0.01 ; 10 \mu \mathrm{M}: 2.14$, $p=0.03$ ). The addition of parthenolide again attenuated the effect (Figure 4A, Supplemental Tables S16 and S17). Regarding the surface expression of adhesion molecules, we observed a higher PECAM surface expression after a $12 \mathrm{~h}$ treatment with $1 \mu \mathrm{M}$ cyclosporine A (subset: 
$99.80 \%, p=0.04$; subset shift: $67.20 \%, p=0.047$ ) via flow cytometry compared to vehicle control (subset: $99.65 \%$, subset shift: $49.75 \%$ ). Treatment with $1 \mu \mathrm{M}$ tacrolimus showed a similar trend but no significant effect (subset: $99.85 \%, p=0.12$; subset shift: $68.65 \%, p=0.10$ ). We further detected a marked but not significant increase of VCAM surface expression after treatment with $1 \mu \mathrm{M}$ cyclosporine A (subset: $87.60 \%, p=0.48$ ) or tacrolimus (subset: $80.10 \%, p=0.75$ ) compared to vehicle control (subset: $70.20 \%$ ). The cyclosporine A effect was especially pronounced in the subset shift $(69.30 \%, p<0.001)$, whereas tacrolimus did not affect the subset shift at all $(48.65 \%, p=0.25)$ compared to vehicle control $(45.35 \%)$. Parthenolide diminished these effects. Treatment with parthenolide alone caused no significant effect (Figure 4B,C, Supplemental Tables S18-S21).
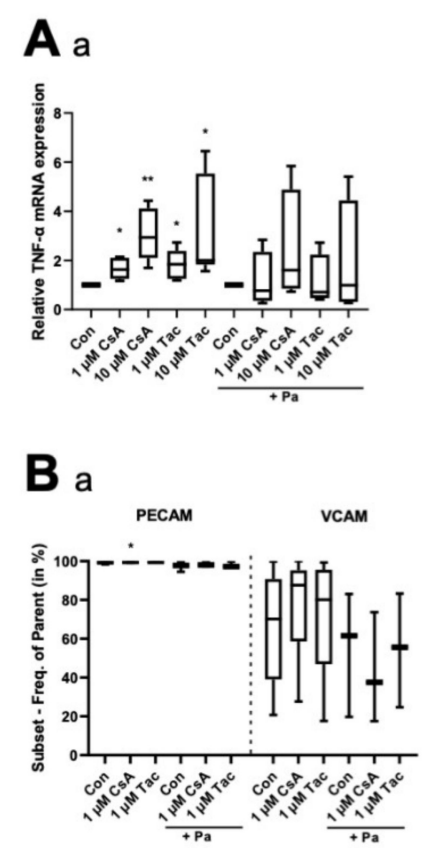

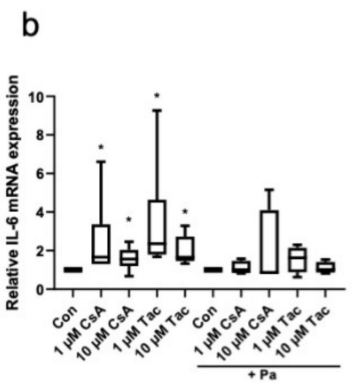

b

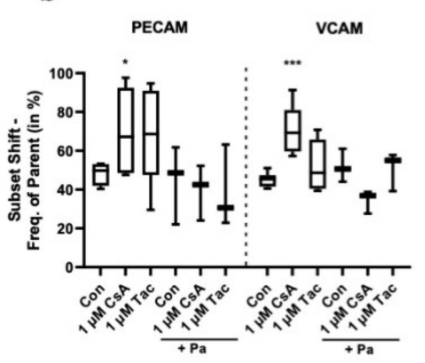

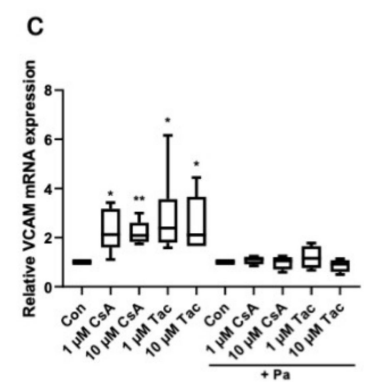

$\mathbf{C}_{\mathrm{a}}$

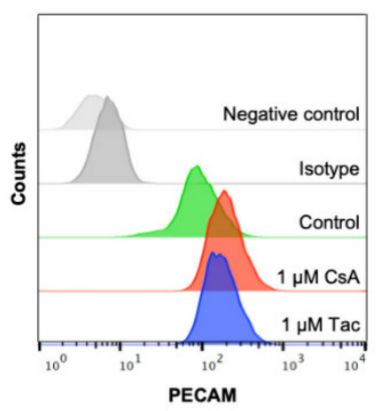

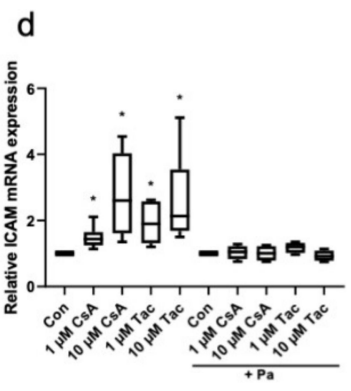

b

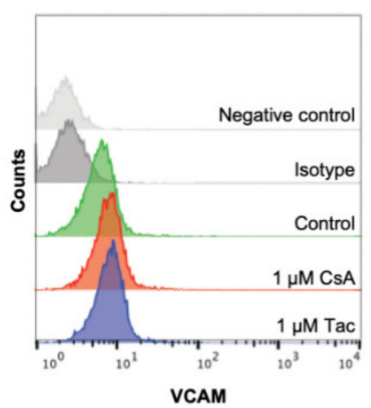

Figure 4. Cyclosporine A (CsA) and tacrolimus (Tac) increased mRNA and cell surface expression of inflammatory cytokines and adhesion molecules in ECFCs. (A) CsA and Tac $(1$ or $10 \mu \mathrm{M})$ significantly induced mRNA expression of the inflammatory cytokines TNF- $\alpha$ (a) and IL-6 (b) and of the adhesion molecules VCAM (c) and ICAM (d). Parthenolide (Pa), an NF- $\mathrm{KB}$ inhibitor, reduced the CsA- and Tac-induced effects. All runs were performed in triplicates. Control group set as 1 , $n=4-6$. In flow cytometry (B), treatment with $1 \mu \mathrm{M}$ CsA significantly increased PECAM and VCAM cell surface expression (a) and shift (b), treatment with $1 \mu \mathrm{M}$ Tac only showed a slight increase. Pa moderated the CsA- and Tac-induced effects, $n=3-6$. (C) Representative measurement of PECAM (a) and VCAM (b) surface expression after treatment with $1 \mu$ M CsA or $1 \mu \mathrm{M}$ Tac. Con—control; CsA—cyclosporine A; Tac—tacrolimus; Pa—parthenolide. ${ }^{*} p<0.05,{ }^{* *} p<0.01,{ }^{* * *} p<0.001$.

2.5. Cyclosporine A and Tacrolimus Induce Phosphorylation and Nuclear Translocation of NF- $\kappa B$ p65 Subunit

NF- $\mathrm{KB}$ is of high importance for the regulation of immune responses. As the phosphorylation and nuclear translocation of its p65 subunit mark key events in its activation, we targeted possible effects of cyclosporine A or tacrolimus on NF- $\mathrm{kB}$ as a mediator of inflammatory reactions in ECFCs. Cyclosporine A and tacrolimus (1 or $10 \mu \mathrm{M})$ significantly increased NF- $\mathrm{KB}$ p65 phosphorylation compared to control (cyclosporine A: $1 \mu \mathrm{M}: 1.55$; $10 \mu \mathrm{M}$ 1.17; tacrolimus: $1 \mu \mathrm{M}$ : 1.39; $10 \mu \mathrm{M}: 1.28, p=0.03)$. TNF- $\alpha$ as a known inducer of NF- $\mathrm{kB}$ activity was used as positive control and displayed a 1.63-fold higher NF- $\mathrm{kB}$ p65 phosphorylation than the control $(p=0.03)$ (Figure 5A,B, Supplemental Table S22). 
A

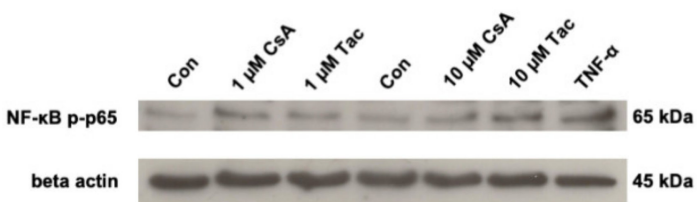

B

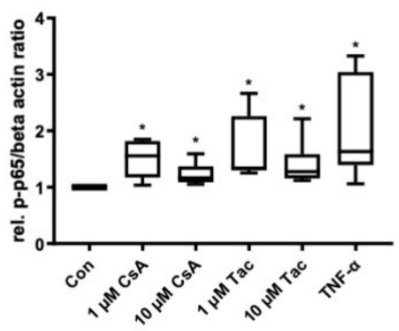

C

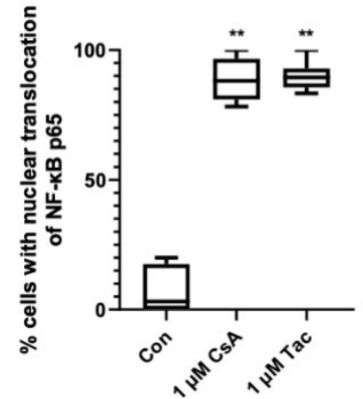

D

Con

$1 \mu \mathrm{M}$ CsA
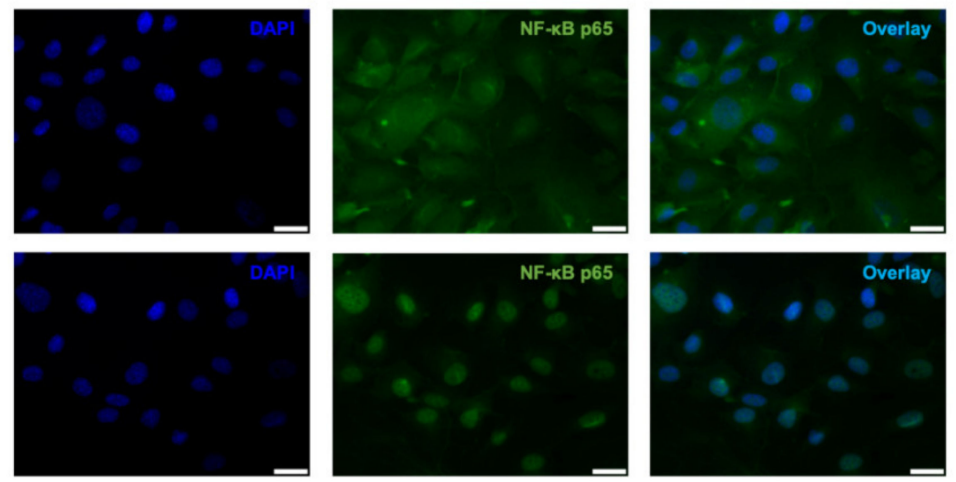

$1 \mu \mathrm{M}$ Tac
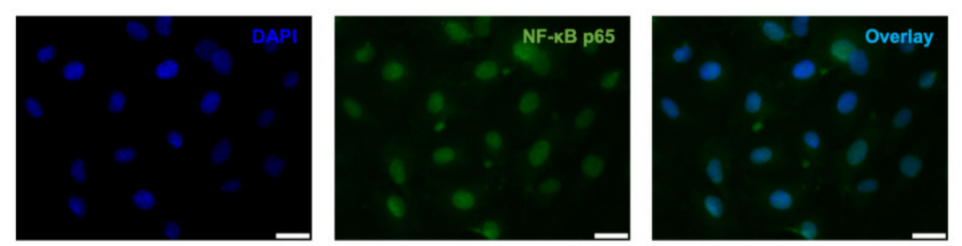

Figure 5. Cyclosporine $\mathrm{A}(\mathrm{CsA})$ and tacrolimus (Tac) induced phosphorylation and nuclear translocation of NF- $\mathrm{kB}$ p65 subunit in ECFCs. (A) Representative immunoblot of NF-kB p65 phosphorylation after 30 min treatment with CsA or Tac (1 or $10 \mu \mathrm{M}$ ). TNF- $\alpha$ was used as positive control. (B) CsA and Tac significantly increased NF- $\mathrm{B}$ p 65 subunit phosphorylation in ECFCs, $n=6$, control group set as 1. (C) Quantification of ECFCs showing nuclear translocation of NF- $k B$ p65 subunit after treatment with $1 \mu \mathrm{M}$ CsA or $1 \mu \mathrm{M}$ Tac for 30 min compared to vehicle control. Cells were counted in 6 randomly taken images per treatment. (D) Representative immunofluorescence images showing NF- $\mathrm{kB}$ p65 (green) nuclear translocation of ECFCs treated with CsA or Tac $(1 \mu \mathrm{M})$ for $30 \mathrm{~min}$, nuclei were counterstained with DAPI (blue), scale bar $25 \mu \mathrm{m}, n=3$. Con-control; CsA—cyclosporine A; Tac—tacrolimus. ${ }^{*} p<0.05,{ }^{* *} p<0.01$, control group set as 1 .

Furthermore, we detected a nuclear translocation of the NF- $\mathrm{kB}$ p65 subunit via immunofluorescence after incubation with cyclosporine A or tacrolimus $(1 \mu \mathrm{M})$, whereas vehicle-treated ECFCs showed a cytoplasmatic distribution of NF-kB p65 subunit (Figure 5C,D, Supplemental Table S23).

\section{Discussion}

In this study, we provide evidence for functional impairment of ECFCs induced by cyclosporine A and tacrolimus. In addition to migration, proliferation, and angiogenesis defects, these immunosuppressants led to a proinflammatory reaction of ECFCs as observed by an increase of gene expression of the inflammatory cytokines TNF- $\alpha$ and IL-6, as well as of the adhesion molecules VCAM and ICAM. Furthermore, we demonstrated modulation of VCAM and PECAM on the ECFC surface. We finally found that this inflammatory reaction was based on a drug-induced modification of NF- $\mathrm{KB}$ p65.

Endothelial dysfunction is a preceding factor in the development of cardiovascular disease, with vascular damage and inflammation leading to atherogenesis $[34,35]$. Endothelial damage is mediated by a number of biological stimuli, such as inflammatory mediators and hypoxia [36]. In transplant patients, endothelial dysfunction is one of the 
most recognized vascular affections. Cyclosporine A and tacrolimus, essential to avoid graft rejection, are considered the main contributors [3,4].

EPCs were identified as endogenous endothelial repair mechanisms mitigating risk factor-induced effects and replacing dysfunctional endothelium [9]. They are impaired in number and functional capacity in heart failure $[8,9,37]$ and hypertension [10], and they inversely correlate with risk factors for coronary artery disease [14]. Therefore, growing evidence suggests that EPCs could be a link between a defective homeostatic or endogenous repair mechanism and vascular dysfunction [38] and are now considered as one of the strongest biomarkers to evaluate endothelial dysfunction [11,12].

In our study, cyclosporine A and tacrolimus impaired key cellular functions of ECFCs, a proliferative subgroup of EPCs, which is in line with findings reported for other cell types. This includes a decreased proliferation of cardiomyocytes and endothelial cells derived from human embryonic stem cells after cyclosporine A or tacrolimus treatment [39]. Furthermore, cyclosporine A inhibited proliferation in human umbilical endothelial, human microvascular, and human renal tubular epithelial cells [40,41]. In renal tubular epithelial cells, cyclosporine A led to cell cycle arrest and inhibited DNA synthesis [42]. Due to their involvement in vascular repair, ECFCs have been identified as a promising model for cellbased therapy, e.g., in ischemia, and have been addressed as a therapeutic target in several studies [12,43-46]. In this context, it has already been demonstrated that cyclosporine A significantly lowers the therapeutic potency of ECFCs. While researchers originally hypothesized that immunosuppression would favor ECFCs' potential of incorporation into damaged vessel walls, it turned out that cyclosporine A caused a significant decrease in reperfusion and poorer limb survival in mice [47]. While cyclosporine A and tacrolimus exert their protective, immunosuppressive effects via calcineurin inhibition, there is some evidence that endothelial dysfunction is independent of it [48].

Cardiovascular ischemia usually results in an increase in VEGF as a physiological response [49,50]. VEGF is known to display various effects on endothelial cells and is considered the master regulator of vascular growth [21,51]. Cyclosporine $\mathrm{A}$ and tacrolimus have been shown to block these VEGF-induced effects. For example, cyclosporine A and tacrolimus inhibited VEGF-induced migration and angiogenesis in different endothelial cells $[49,52]$. This is consistent with our findings that cyclosporine A and tacrolimus hindered VEGF-mediated tube formation. We further demonstrated that cyclosporine A and tacrolimus abrogated VEGF-induced phosphorylation of AKT, a multifunctional intracellular regulator of cell growth, metabolism and survival [21]. This is in line with a study that reported tacrolimus-induced inhibition of AKT phosphorylation of human umbilical vein endothelial cells prior to VEGF stimulation [53]. Furthermore, tacrolimusmediated AKT inhibition caused tube breakdown in endothelial cells, suggesting that tacrolimus induces endothelial dysfunction through attenuation of AKT [48].

Inflammatory activation is a critical component of endothelial dysfunction and atherogenesis $[54,55]$. Apart from their angiogenic properties, ECFCs have also been shown to provide anti-inflammatory effects. Collett et al. reported that ECFC-conditioned medium significantly reduced the expression of adhesion molecules and decreased the number of differentiated lymphocytes typically recruited into the kidney following renal ischemia [16] Furthermore, limb wounds treated with ECFCs showed higher blood vessel quantity in the wound periphery and lower density of neutrophils and macrophages [56]. However, little is known about whether and under what circumstances ECFCs can also harm or contribute to inflammation.

In our study, cyclosporine A and tacrolimus induced the transcription of the inflammatory cytokines TNF- $\alpha$ and IL-6 in ECFCs. This is consistent with the findings of Rodrigues Diez et al., who reported an increase of both cytokines in murine endothelial cells after treatment with these immunosuppressants [33]. Inflammatory cytokines secreted in response to cyclosporine A and tacrolimus may therefore result in an autocrine or paracrine loop leading to further endothelial activation, cytokine production, and deterioration of vascular function [33,57]. They promote endothelial dysfunction, arterial wall remodel- 
ing, arterial stiffening, atherosclerosis, and hypertension [58-60]. The proinflammatory cytokine TNF- $\alpha$ is highly augmented in several cardiovascular and inflammatory diseases and is considered a risk factor for developing these clinical conditions [61]. Regarding ECFCs, TNF- $\alpha$ was shown to inhibit proliferation, migration, and tube formation and further led to barrier breakdown $[62,63]$. Interestingly, ECFCs isolated from patients with systemic lupus erythematodes, an autoimmune inflammatory disease associated with higher cardiovascular risk, showed an elevated expression of IL-6 and were subsequently impaired in their basic physiological function, including proliferation, adhesion, migration, and tube formation [64].

In addition to the stimulation of inflammatory cytokine release, an increased expression of adhesion molecules can be interpreted as an additional sign of inflammatory activation in our study. An enhanced expression of adhesion molecules such as VCAM and ICAM is regarded as a manifestation of endothelial dysfunction accompanied by leukocyte infiltration into the vessel wall and is considered a consequence of chronic exposure to inflammatory cytokines [65-67]. We have already shown the ability of ECFCs to express adhesion molecules in previous studies $[63,68]$. ECFCs secrete proinflammatory mediators and can also upregulate proinflammatory adhesion molecules upon stimulation similar to mature endothelial cells [69], and activated ECFCs increase chemotactic gene expression, synthesize chemotaxis mediators, and favor leukocyte recruitment [70]. The influence of cyclosporine $\mathrm{A}$ and tacrolimus on adhesion molecule expression has been reported controversially. Lehle et al. stated that cyclosporine A and tacrolimus do not affect adhesion molecule expression of human macro- and microvascular endothelial cells and are therefore unlikely to contribute to endothelial cell activation in transplant-associated vasculopathy [71], and Sasakawa et al. described tacrolimus-mediated inhibition of VCAM and ICAM expression on human microvascular endothelial cells [72]. In contrast, Badiwala et al. found a cyclosporine A- and tacrolimus-induced increase in ICAM expression in human coronary endothelial cells [73], and Kidokoro et al. described that expression of ICAM mRNA was enhanced in glomeruli after tacrolimus treatment and resulted in macrophage infiltration into the glomeruli. Consequently, they hypothesized that cyclosporine A- and tacrolimus-induced inflammatory reactions could play a role in vascular injury and in complications associated with their long-term use [74]. Rodrigues Diez et al. found a significant cyclosporine A- and tacrolimus-induced increase of VCAM and ICAM mRNA expression and further demonstrated a higher ICAM-release of murine endothelial cells [33]. Apart from gene transcription and surface expression, a possible cyclosporine A- and tacrolimus-induced release of inflammatory cytokines through ECFCs should be targeted in further studies. With our current results, we provide another piece of the puzzle to explain the development of cardiovascular complications in cyclosporine A and tacrolimus therapy and support the hypothesis that the immune activity of EPCs might play a pathophysiologic role in the evolution of cardiovascular disease [75].

Based on the observed nuclear translocation and phosphorylation of the NF- $\mathrm{kB}$ p65 subunit, we further suggest that inflammatory reactions in ECFCs may be mediated via NF- $\mathrm{kB}$. This is consistent with the available literature indicating that endothelial dysfunction generated by inflammatory cytokines is dependent on the NF- $\mathrm{kB}$ pathway [76]. NF- $\mathrm{kB}$ activation can induce the transcription of a large number of inflammatory genes in vascular cells and other cell types, including cytokines, chemokines, and adhesion molecules [25]. NF- $\mathrm{KB}$ expression correlates with upregulation of chemokines in human cardiovascular disease $[25,77,78]$. Therefore, activation of NF- $\mathrm{kB}$ is considered to contribute to vascular injury, hypertension, and systemic inflammation and further promotes atherosclerosis [79-82]. Badiwala et al. reported that cyclosporine A upregulated NF-kB p65 activity in human coronary endothelial cells [73]. Especially the phosphorylation at Serine 536, which we have shown to be inducible by cyclosporine A and tacrolimus as well, is suggested to be critical for increased NF- $\mathrm{kB}$ and subsequent NF-kB-dependent gene activation [83] and associated with a preserved inflammatory gene expression [33]. Nevertheless, whether treatment with cyclosporine A or tacrolimus leads to complete activation of NF- $\mathrm{kB}$ was not revealed in our 
study and would be of great interest for future research. The NF- $\mathrm{B}$ inhibitor parthenolide attenuated cyclosporine A- and tacrolimus-induced inflammatory effects in ECFCs. It has been shown that pharmacological inhibition of NF- $\mathrm{KB}$ activation ameliorates hypertension, cardiovascular injury, and atherogenesis $[81,84,85]$. NF- $\mathrm{kB}$ suppression may therefore represent a therapeutic approach facing cardiovascular complications in transplant patients. Another promising substance group consists of statins. Statins are a class of lipid-lowering drugs that reduce morbidity and mortality in patients at high cardiovascular risk [86,87] and provide several beneficial pleiotropic effects, including anti-atherothrombotic properties and immune modulation $[88,89]$. Statin treatment prevented TNF- $\alpha$-induced NF- $\mathrm{B}$ activation and the nuclear translocation of the NF- $\mathrm{B}$ p 65 subunit in human endothelial cells [90] and in mice [91]. We recently identified the HMG-CoA reductase inhibitor pravastatin as a promising potentiator of ECFC function [92]. Further investigations may address to what extent statins are able to block cyclosporine A- and tacrolimus-induced functional impairment and inflammatory reactions in ECFCs.

As our study is based on in vitro data, the results cannot be transferred directly to the in vivo situation, and should be confirmed under in vivo conditions. The first approach in this context could be the investigation of ECFCs derived from individuals taking cyclosporine A or tacrolimus, which is currently explored by our group.

In conclusion, we demonstrate the induction of functional defects of ECFCs as well as the stimulation of inflammatory signals by cyclosporine A and tacrolimus. Since ECFCs are important players in vascular repair, these effects may be an explanatory approach for poor vascular health in transplant patients. The interaction of inflammation and functional capacities requires further investigation. Anti-inflammatory therapies may provide an option to improve vascular health in those affected. Our results consequently contribute to mechanistic explanations linking hypertension, vascular disease, and metabolic alterations observed in patients under long-term cyclosporine A or tacrolimus treatment.

\section{Materials and Methods}

\subsection{ECFC Isolation, Culture, and Characterization}

The study was approved by the Institutional Review Board of Hannover Medical School (approval no. 1443-2012). Written informed consent was obtained from each participant. Umbilical cord blood from 9 healthy, uncomplicated pregnancies was collected immediately after delivery. All pregnancies were normotensive and without proteinuria, ending with the delivery of a healthy singleton. None of the control patients referred a clinical history of diabetes or a hypertensive, vascular, or renal disease, smoking or the use of illicit drugs.

ECFCs were isolated as previously described by our group [93]. Density gradient centrifugation was performed to isolate the cord blood mononuclear cell (CBMC) fraction. Up to $1 \times 10^{7}$ cells per well were plated in endothelial growth medium 2 (EGM-2) consisting of endothelial basal medium (EBM-2; Lonza, Basel, Switzerland) supplemented with supplier provided supplements, 10\% fetal bovine serum (FBS; Harvard Bioscience, Holliston, MA, USA) and 1\% penicillin/streptomycin (P/S; Bio\&Sell, Feucht, Nürnberg, Germany) on collagen-coated 6-well plates (BioCoat; Corning, NY, USA) and incubated at $37^{\circ} \mathrm{C}, 5 \% \mathrm{CO}_{2}$ supply. First ECFC colonies were noted as circumscribed monolayers of rapidly proliferating cells with cobblestone morphology and characterized by flow cytometry with the appropriate antibodies (CD31 (130-117-390; BD Biosciences, San Jose, CA, USA), CD45 (555483; BD Biosciences), and CD133 (130-090-826; Miltenyi Biotec, Bergisch Gladbach, Germany)) and the corresponding isotype controls (BD Biosciences, Miltenyi Biotec). ECFCs were used for experiments in cell culture passages 4-6.

\subsection{Cell Impedance Assay}

The cell index, a parameter reflecting cell size, adhesion, and proliferation, was calculated with an xCelligence Real-Time Cell Analyzer (Roche, Basel, Switzerland), which allows continuous cell monitoring in real time. The electrical impedance caused by ad- 
herent cells is converted into cell indices by the xCelligence software (v.1.2.1). Then, $0.25 \times 10^{4}$ cells of 5 ECFC lines were seeded in quadruplicates in EGM-2 with $8 \%$ FBS and $1 \% \mathrm{P} / \mathrm{S}$ onto a gold-coated E-Plate View 96-well plate (Roche) and then placed into the Real-Time Cell Analyzer SP station, positioned in a $37{ }^{\circ} \mathrm{C}$ incubator with $5 \% \mathrm{CO}_{2}$ supply. Following adherence, the cell indices were aligned and then treated with different concentrations of cyclosporine A (Enzo Life Sciences, Farmingdale, NY, USA) or tacrolimus (InvivoGen, San Diego, CA, USA) $(0.01-10 \mu \mathrm{M})$ diluted in EGM-2 with 8\% FBS and 1\% $\mathrm{P} / \mathrm{S}$. Cell indices were continuously monitored for the following $72 \mathrm{~h}$. For all experiments, concentrations of cyclosporine A and tacrolimus were chosen based on those that were described as effective in other publications using in vitro models. These covered anticipated in vivo doses but excluded doses with significant cytotoxicity [42,52,53,94,95].

\subsection{Chemotaxis Assay}

To analyze ECFCs' ability of directional cell migration in the presence or absence of cyclosporine A or tacrolimus, a modified Boyden chamber assay was performed to determine chemotactic motility. Transwell inserts with an $8 \mu \mathrm{m}$ microporous membrane (ThinCerts; Greiner, Kremsmünster, Austria) were placed in a 12-well-plate; $5 \times 10^{4}$ ECFCs from 4 cell lines were seeded per transwell insert into the upper side of the chamber in serum-free EBM-2 medium including $1 \%$ P/S. FBS (10\%) was used as a chemoattractant on the lower side of the chamber. Different concentrations $(0.01-10 \mu \mathrm{M})$ of cyclosporine A or tacrolimus were added to both sides of the chamber. Dimethyl sulfoxide (DMSO, Sigma-Aldrich, St. Louis, MO, USA) was used as vehicle control. The cells were allowed to migrate for $4 \mathrm{~h}$ before the inserts were removed, and the non-migrated cells were detached from the upper surface of the membrane with a cotton bud. The inserts were fixed in $3 \%$ $w / v$ paraformaldehyde and $2 \% w / v$ sucrose in phosphate buffered saline (PBS) for $10 \mathrm{~min}$, followed by 2 washing steps with PBS. Afterwards, the migrated cells on the bottom side of the membrane were counterstained with 4',6-diamidino-2-phenylindole (DAPI, Thermo Fisher Scientific, Waltham, MA, USA), followed by mounting in antifade fluorescence mounting medium (Pro-LongGold; Thermo Fisher Scientific). Five pictures per membrane were randomly taken with a Leica DMI 6000 B microscope (Leica, Wetzlar, Germany). DAPI-stained cells were counted with ImageJ 1.50b (National Institutes of Health).

\subsection{Migration Assay}

A scratch wound healing assay was used to evaluate cell migration; $5 \times 10^{4}$ ECFCs from 4 lines were seeded in duplicates on gelatin-coated (Sigma-Aldrich) wells of 6-well culture plates with EGM-2 containing 10\% FBS and 1\% P/S and grown to confluence. The cell monolayers were scratched with a sterile P1000 pipette tip to create a wound and washed with PBS. Afterwards, cells were cultured in EBM-2 containing 2.5\% FBS and $1 \% \mathrm{P} / \mathrm{S}$ with different concentrations of cyclosporine A or tacrolimus $(0.01-10 \mu \mathrm{M})$ or vehicle control. Phase-contrast microscopic images were taken immediately after scratching and again after $18 \mathrm{~h}$ with a Leica DMI $6000 \mathrm{~B}$ microscope. Non-populated scratch areas were quantified by ImageJ $1.50 \mathrm{~b}$. The area after $18 \mathrm{~h}$ was subtracted from the area at the beginning to obtain the remigrated area.

\subsection{In Vitro Angiogenesis Assay}

To compare the capacity of ECFCs to form capillary tubule-like networks in the presence or absence of cyclosporine A or tacrolimus, $1.4 \times 10^{4}$ cells/well from 4 cell lines were placed in triplicates in 96-well plates pre-coated with $30 \mu \mathrm{L}$ growth factor reduced Matrigel (BD Biosciences). The cells were incubated for $14 \mathrm{~h}$ with different concentrations of cyclosporine A or tacrolimus (0.01-10 $\mu \mathrm{M}$ ) or vehicle control in EBM-2 with $1 \% \mathrm{P} / \mathrm{S}$ and VEGF (Thermo Fisher Scientific, $25 \mathrm{ng} / \mathrm{mL}$ ). The optimal time frame was determined in advance by live cell imaging of untreated ECFCs from healthy subjects and further used in previous studies [96-98]. Phase-contrast microscopic images were taken with a Leica DMI $6000 \mathrm{~B}$ microscope. Total tube length was calculated with Image $1.50 \mathrm{~b}$. 


\subsection{Isolation of Proteins and Immunoblotting}

For analyses of proteins, ECFCs from 3-4 cell lines were grown to $80-90 \%$ confluence in $10 \mathrm{~cm}$ dishes (Sarstedt, Nümbrecht, Germany). For analysis of AKT phosphorylation, ECFCs were incubated with cyclosporine A or tacrolimus $(1$ or $10 \mu \mathrm{M})$ in EBM-2 with $1 \% \mathrm{P} / \mathrm{S}$ (and without FBS or supplements) for $1 \mathrm{~h}$ before addition of VEGF ( $25 \mathrm{ng} / \mathrm{mL}$ ) for $10 \mathrm{~min}$. For analysis of NF-KB p65 phosphorylation, ECFCs were incubated with cyclosporine A or tacrolimus ( 1 or $10 \mu \mathrm{M})$ for $30 \mathrm{~min}$. TNF- $\alpha(10 \mathrm{ng} / \mathrm{mL})$ was used as positive control. ECFCs were then detached with trypsin-EDTA (Bio\&Sell), washed with PBS, and lysed with lysis buffer as previously described [93]. Protein concentration was determined by the Bradford protein assay [99]. Proteins were separated by electrophoresis on SDS-polyacrylamide gels and transferred to nitrocellulose membranes (GE Healthcare, Waukesha, WI, USA). After blocking for $1 \mathrm{~h}$ with 1\% Roti-Block (Carl Roth, Karlsruhe, Germany) in $\mathrm{H}_{2} \mathrm{O}$, the membrane was incubated overnight at $4{ }^{\circ} \mathrm{C}$ with appropriate antibodies (1:1,000 pAKT S473 and 1:1,000 AKT [9271S and 9272S, Cell Signaling, Danvers, MA, USA], 1:1,000 NF-kB p-p65 [sc-136548, Santa Cruz, Dallas, TX, USA], 1:3,000 anti-betaactin (A54410, Sigma-Aldrich). After washing 3 times with PBS-T $(0.1 \% v / v)$, the secondary antibody was added (1:3,000 (or 1:5,000 for beta-actin) goat anti-mouse or goat anti-rabbit horseradish peroxidase; GE Healthcare) in 1\% Roti-Block for $2 \mathrm{~h}$ at room temperature. Visualization of immunoblot bands was performed by using ECL chemiluminescence (Thermo Fisher Scientific), and analysis was carried out with Image J 1.50b.

\subsection{Quantitative Real-Time PCR ( $q$ RT-PCR)}

ECFCs from 4-6 lines were treated with cyclosporine A or tacrolimus (1 or $10 \mu \mathrm{M})$ for $6 \mathrm{~h}$. In the case of NF- $\kappa \mathrm{B}$ inhibition, $10 \mu \mathrm{M}$ parthenolide (Enzo Life Sciences) was added $1 \mathrm{~h}$ prior. RNA was purified using the RNeasy Plus Mini Kit (Qiagen, Hilden, Germany) according to the manufacturer's instructions. For the cDNA synthesis, RNA was diluted with diethylpyrocarbonate (DEPC)-treated water and denatured at $68^{\circ} \mathrm{C}$ for $10 \mathrm{~min}$ in a thermocycler (PTC 200, Biozym Scientific GmbH, Hessisch Oldendorf, Germany). Then, High-Capacity cDNA Reverse Transcription (RT) master mix (Applied Biosystems, Waltham, MA, USA) was added. For qRT-PCR, cDNA and master mix (FastStart Universal SYBR Green, Roche) were pipetted into the appropriate strip tubes $(0.1 \mathrm{~mL})$. Real-time PCR was performed on a Rotor-Gene 6000 (Qiagen) for 40 cycles. For each treatment, runs were performed in triplicates. The primer sequences used to determine mRNA levels are described in Table 1. Ct values were automatically generated, and relative quantification of gene expression was calculated by standard $\Delta \mathrm{Ct}$ method using the expression of $18 \mathrm{~S}$ rRNA as reference.

Table 1. Primer sequences for target genes.

\begin{tabular}{ccc}
\hline Gene & \multicolumn{1}{c}{ Sense } & Antisense \\
\hline$T N F-\alpha$ & CCCAGGCAGTCAGATCATCTT & TCAGCTTGAGGGTTTGCTACA \\
$I L-6$ & GGTACATCCTCGACGGCATCT & GTGCCTCTTTGCTGCTTTCAC \\
$V C A M$ & ATGGTCGTGATCCTTGGAGC & AGATTCTGGGGTGGTCTCGA \\
$I C A M$ & GAACCAGAGCCAGGAGACAC & CTTCACTGTCACCTCGGTCC \\
RNA18S1 & ACATCCAAGGAAGGCAGCAG & TTTTCGTCACTACCTCCCCG \\
\hline
\end{tabular}

\subsection{Flow Cytometry}

Flow cytometry analysis was performed to measure apoptosis and further to detect adhesion molecule expression on ECFCs' surface. For apoptosis measurement, ECFCs from 5 lines were harvested with trypsin/EDTA after $48 \mathrm{~h}$ of treatment with cyclosporine A or tacrolimus $(0.01-10 \mu \mathrm{M})$ as described for the cell impedance assay. For adhesion molecule detection, ECFCs from 3-5 lines were treated with $1 \mu \mathrm{M}$ cyclosporine A or $1 \mu \mathrm{M}$ tacrolimus for $12 \mathrm{~h}$. For NF- $\mathrm{kB}$ inhibition, $10 \mu \mathrm{M}$ parthenolide (Enzo Life Science) was added $1 \mathrm{~h}$ prior to cyclosporine A or tacrolimus treatment. ECFCs were harvested by incubating with accutase (Capricorn, Ebsdorfergrund, Germany) for $15 \mathrm{~min}$ at room 
temperature. In both experimental settings, ECFCs were centrifuged and washed with flow cytometry buffer (PBS, $2 \%$ FBS). Then, $1 \times 10^{5}$ cells were blocked with intraglobin ( $5 \mathrm{mg} / \mathrm{mL}$; Gamunex 10\%, Grifols, Frankfurt am Main, Germany) for $1 \mathrm{~min}$, followed by incubation at $4{ }^{\circ} \mathrm{C}$ for 30 min with an Annexin V antibody (\#640906, Biolegend, San Diego, CA, USA) or with VCAM1 APC (BioLegend), and PECAM1 FITC (BioLegend) antibodies or the corresponding isotype controls, respectively. UV radiation with a transilluminator (Biostep, Jahnsdorf, Germany) for $30 \mathrm{~min}$ was used as positive control for apoptosis for gating strategy. For apoptosis analysis, propidiumiodide (PI, Sigma-Aldrich, $10 \mu \mathrm{g} / \mathrm{mL}$ ) was added $1 \mathrm{~min}$ prior to measurement. Flow cytometry measurements were performed on a BD FACS Calibur Flow Cytometer (BD Biosciences), and results were analyzed using FlowJo X Software v.10 (Tree Star, FlowJo ILC; Ashland, OR, USA).

\subsection{Immunocytochemistry}

Immunocytochemistry was used to demonstrate the expression and localization of NF-kB p65 in ECFCs in the presence or absence of cyclosporine A or tacrolimus. ECFCs from 3 lines were grown to $80-90 \%$ confluence on coverslip glasses. After treatment with cyclosporine A or tacrolimus $(1 \mu \mathrm{M})$ for $30 \mathrm{~min}$, cells were washed with PBS and fixed with $3 \% w / v$ paraformaldehyde $/ 2 \% w / v$ sucrose in PBS for 10 min. After washing 3 times with PBS and permeabilization with $0.2 \%(v / v)$ Triton X-100 (Sigma-Aldrich) in PBS, the cells were incubated with an NF-kB p65 antibody (sc-8008 AF488, Santa Cruz, CA, USA) in antibody diluent [ $2 \%(v / v)$ normal goat serum (Thermo Fisher Scientific), PBS] for $2 \mathrm{~h}$. The cells were washed 3 times with PBS and incubated with Alexa Fluor anti-rabbit IgG 488 (Thermo Fisher Scientific) for $2 \mathrm{~h}$. Nuclear DNA was stained with DAPI, and coverslip glasses were mounted in antifade fluorescence mounting medium. Image acquisition was performed with a Leica DMI $6000 \mathrm{~B}$ microscope. For quantification of ECFCs showing nuclear translocation of NF- $\mathrm{BB}$ p65, cells were counted in 6 randomly taken images per treatment.

\subsection{Lactate Dehydrogenase Cytotoxicity Assay}

Cytotoxicity was assessed by the release of lactate dehydrogenase (LDH) into the medium. Therefore, the medium of 3 ECFC lines treated with DMSO as vehicle control, cyclosporine A or tacrolimus ( 1 or $10 \mu \mathrm{M}$ ) for $18 \mathrm{~h}$ was collected after the scratch wound healing assay. The LDH measurement was performed as recommended in the manufacturer's instructions using the in vitro toxicology kit (\#TOX7-1KT, Sigma-Aldrich). LDH release was expressed as a percentage of maximum releasable $\mathrm{LDH}$ of an equivalent ECFC sample after complete cell lysis obtained by sonification in the same cell culture media used for experimentation (positive control).

\subsection{Statistical Analysis}

Normality distribution was tested by Shapiro-Wilk or D'Agostino normality test and considered before each statistical test. Wilcoxon signed-rank test or one-sample ttest were applied for normalized data, whereas unpaired t-test or Mann-Whitney test were applied for not normalized data. A two-way ANOVA was applied for grouped analyses. Experimental data are presented as median. Additional statistical information, including interquartile ranges (IQR), is placed in the corresponding supplemental tables. The obtained individual measured values $(n)$ from each experiment were analyzed with Prism 9 (GraphPad Software, La Jolla, CA, USA). A significant difference is indicated by values of $p<0.05, p<0.01, p<0.001$.

Supplementary Materials: The following are available online at https:/ / www.mdpi.com/article/10 $.3390 /$ ijms22189696/s1.

Author Contributions: Conceptualization, N.M., B.S.-H., and F.v.V.-H.; methodology, N.M., L.B., B.S.-H., and F.v.V.-H.; validation, N.M., B.S.-H., and F.v.V.-H.; formal analysis, N.M., B.S.-H., and F.v.V.-H.; investigation, N.M., L.B., B.S.-H., and F.v.V.-H.; resources, C.v.K. and F.v.V.-H.; data curation, 
N.M.; writing—original draft preparation, N.M. and F.v.V.-H.; writing—review and editing, N.M., L.B., B.S.-H., and F.v.V.-H.; visualization, N.M.; supervision, F.v.V.-H.; project administration, B.S.-H. and F.v.V.-H.; funding acquisition, B.S.-H. and F.v.V.-H. All authors have read and agreed to the published version of the manuscript.

Funding: This work was supported by a grant from the German Federal Ministry of Education and Research (reference number: 01EO1302).

Institutional Review Board Statement: The study was conducted according to the guidelines of the Declaration of Helsinki and approved by the Ethics Committee of Hannover Medical School (Ethical Approval Number 1443-2012, 6 January 2012).

Informed Consent Statement: Written informed consent was obtained from all subjects involved in the study.

Data Availability Statement: The data that support the findings of this study are available from the corresponding author upon reasonable request.

Acknowledgments: The authors thank Katja Richter for technical assistance. They further thank the faculty, residents, and staff of the Gynecology Research Unit and the Division of Obstetrics at Hannover Medical School for their support in recruiting participants and collecting blood samples. The authors thank the Claudia von Schilling Foundation for supporting the Gynecology Research Unit with the xCelligence instrument.

Conflicts of Interest: The authors declare no conflict of interest.

\section{References}

1. Waller, D.G.; Sampson, A.P. The immune response and immunosuppressant drugs. In Medical Pharmacology and Therapeutics; Elsevier: Amsterdam, The Netherlands, 2018; pp. 439-449. ISBN 9780702071676.

2. Barbarino, J.M.; Staatz, C.E.; Venkataramanan, R.; Klein, T.E.; Altman, R.B. PharmGKB summary: Cyclosporine and tacrolimus pathways. Pharmacogenet. Genom. 2013, 23, 563-585. [CrossRef]

3. Issa, N.; Braun, W.E. Immunosuppression for Renal Transplant Patients and Common Medical Problems in Renal Transplantation. Available online: http:/ / www.clevelandclinicmeded.com/medicalpubs/diseasemanagement/nephrology/immunosuppressionand-renal-transplant/ (accessed on 4 May 2018).

4. Hardinger, K.; Magee, C.C. Pharmacology of Cyclosporine and Tacrolimus. Available online: https://www.uptodate.com/ contents/pharmacology-of-cyclosporine-and-tacrolimus (accessed on 4 May 2018).

5. Zoja, C.; Furci, L.; Ghilardi, F.; Zilio, P.; Benigni, A.; Remuzzi, G. Cyclosporin-induced endothelial cell injury. Lab. Invest. 1986, 55, 455-462. [PubMed]

6. Trapp, A.; Weis, M. The impact of immunosuppression on endothelial function. J. Cardiovasc. Pharmacol. 2005, 45, 81-87. [CrossRef] [PubMed]

7. Asahara, T.; Murohara, T.; Sullivan, A.; Silver, M.; van der Zee, R.; Li, T.; Witzenbichler, B.; Schatteman, G.; Isner, J.M. Isolation of putative progenitor endothelial cells for angiogenesis. Science 1997, 275, 964-967. [CrossRef] [PubMed]

8. Michowitz, Y.; Goldstein, E.; Wexler, D.; Sheps, D.; Keren, G.; George, J. Circulating endothelial progenitor cells and clinical outcome in patients with congestive heart failure. Heart 2007, 93, 1046-1050. [CrossRef] [PubMed]

9. Andreou, I.; Tousoulis, D.; Tentolouris, C.; Antoniades, C.; Stefanadis, C. Potential role of endothelial progenitor cells in the pathophysiology of heart failure: Clinical implications and perspectives. Atherosclerosis 2006, 189, 247-254. [CrossRef]

10. Luo, S.; Xia, W.; Chen, C.; Robinson, E.A.; Tao, J. Endothelial progenitor cells and hypertension: Current concepts and future implications. Clin. Sci. 2016, 130, 2029-2042. [CrossRef]

11. Hill, J.M.; Zalos, G.; Halcox, J.P.J.; Schenke, W.H.; Waclawiw, M.A.; Quyyumi, A.A.; Finkel, T. Circulating endothelial progenitor cells, vascular function, and cardiovascular risk. N. Engl. J. Med. 2003, 348, 593-600. [CrossRef]

12. Sen, S.; McDonald, S.P.; Coates, P.T.H.; Bonder, C.S. Endothelial progenitor cells: Novel biomarker and promising cell therapy for cardiovascular disease. Clin. Sci. 2011, 120, 263-283. [CrossRef]

13. Fadini, G.P.; Losordo, D.; Dimmeler, S. Critical reevaluation of endothelial progenitor cell phenotypes for therapeutic and diagnostic use. Circ. Res. 2012, 110, 624-637. [CrossRef] [PubMed]

14. Vasa, M.; Fichtlscherer, S.; Aicher, A.; Adler, K.; Urbich, C.; Martin, H.; Zeiher, A.M.; Dimmeler, S. Number and migratory activity of circulating endothelial progenitor cells inversely correlate with risk factors for coronary artery disease. Circ. Res. 2001, 89, E1-E7. [CrossRef] [PubMed]

15. Ingram, D.A.; Mead, L.E.; Tanaka, H.; Meade, V.; Fenoglio, A.; Mortell, K.; Pollok, K.; Ferkowicz, M.J.; Gilley, D.; Yoder, M.C. Identification of a novel hierarchy of endothelial progenitor cells using human peripheral and umbilical cord blood. Blood 2004, 104, 2752-2760. [CrossRef] 
16. Collett, J.A.; Mehrotra, P.; Crone, A.; Shelley, W.C.; Yoder, M.C.; Basile, D.P. Endothelial colony-forming cells ameliorate endothelial dysfunction via secreted factors following ischemia-reperfusion injury. Am. J. Physiol. Renal Physiol. 2017, 312, F897-F907. [CrossRef] [PubMed]

17. Du, F.; Zhou, J.; Gong, R.; Huang, X.; Pansuria, M.; Virtue, A.; Li, X.; Wang, H.; Yang, X.-F. Endothelial progenitor cells in atherosclerosis. Front. Biosci. 2012, 17, 2327-2349. [CrossRef] [PubMed]

18. Smadja, D.M. Vasculogenic Stem and Progenitor Cells in Human: Future Cell Therapy Product or Liquid Biopsy for Vascular Disease. In Stem Cells: Therapeutic Applications; Ratajczak, M.Z., Ed.; Springer: Cham, Switzerland, 2020; pp. 215-237. ISBN 978-3-030-31206-0.

19. Medina, R.J.; Barber, C.L.; Sabatier, F.; Dignat-George, F.; Melero-Martin, J.M.; Khosrotehrani, K.; Ohneda, O.; Randi, A.M.; Chan, J.K.Y.; Yamaguchi, T.; et al. Endothelial Progenitors: A Consensus Statement on Nomenclature. Stem Cells Transl. Med. 2017, 6, 1316-1320. [CrossRef]

20. Dimmeler, S.; Aicher, A.; Vasa, M.; Mildner-Rihm, C.; Adler, K.; Tiemann, M.; Rütten, H.; Fichtlscherer, S.; Martin, H.; Zeiher, A.M. HMG-CoA reductase inhibitors (statins) increase endothelial progenitor cells via the PI 3-kinase/Akt pathway. J. Clin. Invest. 2001, 108, 391-397. [CrossRef]

21. Gerber, H.P.; McMurtrey, A.; Kowalski, J.; Yan, M.; Keyt, B.A.; Dixit, V.; Ferrara, N. Vascular endothelial growth factor regulates endothelial cell survival through the phosphatidylinositol 3'-kinase/Akt signal transduction pathway. Requirement for Flk1/KDR activation. J. Biol. Chem. 1998, 273, 30336-30343. [CrossRef] [PubMed]

22. Willerson, J.T.; Ridker, P.M. Inflammation as a cardiovascular risk factor. Circulation 2004, 109, II-2-II-10. [CrossRef]

23. Rusterholz, C.; Hahn, S.; Holzgreve, W. Role of placentally produced inflammatory and regulatory cytokines in pregnancy and the etiology of preeclampsia. Sem. Immunopathol. 2007, 29, 151-162. [CrossRef] [PubMed]

24. Calabrese, F. Infection and inflammation in the cardiovascular system. Cardiovasc. Res. 2003, 60, 1-4. [CrossRef]

25. Van der Heiden, K.; Cuhlmann, S.; Le Luong, A.; Zakkar, M.; Evans, P.C. Role of nuclear factor kappaB in cardiovascular health and disease. Clin. Sci. 2010, 118, 593-605. [CrossRef] [PubMed]

26. Lawrence, T. The nuclear factor NF-kappaB pathway in inflammation. Cold Spring Harb. Perspect. Biol. 2009, 1, a001651. [CrossRef] [PubMed]

27. Chandel, N.S.; Trzyna, W.C.; McClintock, D.S.; Schumacker, P.T. Role of oxidants in NF-kappa B activation and TNF-alpha gene transcription induced by hypoxia and endotoxin. J. Immunol. 2000, 165, 1013-1021. [CrossRef]

28. Brasier, A.R. The nuclear factor-kappaB-interleukin-6 signalling pathway mediating vascular inflammation. Cardiovasc. Res. 2010, 86, 211-218. [CrossRef]

29. Maguire, O.; Collins, C.; O’Loughlin, K.; Miecznikowski, J.; Minderman, H. Quantifying nuclear p65 as a parameter for NF-кB activation: Correlation between ImageStream cytometry, microscopy, and Western blot. Cytometry A 2011, 79, 461-469. [CrossRef] [PubMed]

30. Botella, L.M.; Puig-Kröger, A.; Almendro, N.; Sánchez-Elsner, T.; Muñoz, E.; Corbí, A.; Bernabéu, C. Identification of a functional NF-kappa B site in the platelet endothelial cell adhesion molecule-1 promoter. J. Immunol. 2000, 164, 1372-1378. [CrossRef]

31. Cho, M.-L.; Ju, J.H.; Kim, K.-W.; Moon, Y.-M.; Lee, S.-Y.; Min, S.-Y.; Cho, Y.-G.; Kim, H.-S.; Park, K.-S.; Yoon, C.-H.; et al. Cyclosporine A inhibits IL-15-induced IL-17 production in CD4+ T cells via down-regulation of PI3K/Akt and NF-kappaB. Immunol. Lett. 2007, 108, 88-96. [CrossRef]

32. González-Guerrero, C.; Ocaña-Salceda, C.; Berzal, S.; Carrasco, S.; Fernández-Fernández, B.; Cannata-Ortiz, P.; Egido, J.; Ortiz, A.; Ramos, A.M. Calcineurin inhibitors recruit protein kinases JAK2 and JNK, TLR signaling and the UPR to activate NF- $\mathrm{KB}-\mathrm{mediated}$ inflammatory responses in kidney tubular cells. Toxicol. Appl. Pharmacol. 2013, 272, 825-841. [CrossRef]

33. Rodrigues-Diez, R.; González-Guerrero, C.; Ocaña-Salceda, C.; Rodrigues-Diez, R.R.; Egido, J.; Ortiz, A.; Ruiz-Ortega, M.; Ramos, A.M. Calcineurin inhibitors cyclosporine A and tacrolimus induce vascular inflammation and endothelial activation through TLR4 signaling. Sci. Rep. 2016, 6, 27915. [CrossRef]

34. Gimbrone, M.A.; García-Cardeña, G. Endothelial Cell Dysfunction and the Pathobiology of Atherosclerosis. Circ. Res. 2016, 118, 620-636. [CrossRef] [PubMed]

35. Van Gaal, L.F.; Mertens, I.L.; de Block, C.E. Mechanisms linking obesity with cardiovascular disease. Nature 2006, 444, 875-880. [CrossRef]

36. Konukoglu, D.; Uzun, H. Endothelial Dysfunction and Hypertension. Adv. Exp. Med. Biol. 2017, 956, 511-540. [CrossRef] [PubMed]

37. Premer, C.; Kanelidis, A.J.; Hare, J.M.; Schulman, I.H. Rethinking Endothelial Dysfunction as a Crucial Target in Fighting Heart Failure. Mayo Clin. Proc. Innov. Qual. Outcomes 2019, 3, 1-13. [CrossRef]

38. Mohan, S.; Barsalou, J.; Bradley, T.J.; Slorach, C.; Reynolds, J.A.; Hasni, S.; Thompson, B.; Ng, L.; Levy, D.; Silverman, E.; et al. Endothelial progenitor cell phenotype and function are impaired in childhood-onset systemic lupus erythematosus. Arthritis Rheumatol. 2015, 67, 2257-2262. [CrossRef]

39. Földes, G.; Mioulane, M.; Kodagoda, T.; Lendvai, Z.; Iqbal, A.; Ali, N.N.; Schneider, M.D.; Harding, S.E. Immunosuppressive agents modulate function, growth, and survival of cardiomyocytes and endothelial cells derived from human embryonic stem cells. Stem Cells Dev. 2014, 23, 467-476. [CrossRef]

40. Storogenko, M.; Pech-amsellem, M.-A.; Kerdine, S.; Rousselet, F.; Pallardy, M. Cyclosporin-A inhibits human endothelial cells proliferation through interleukin-6-dependent mechanisms. Life Sci. 1997, 60, 1487-1496. [CrossRef] 
41. Esposito, C.; Fornoni, A.; Cornacchia, F.; Bellotti, N.; Fasoli, G.; Foschi, A.; Mazzucchelli, I.; Mazzullo, T.; Semeraro, L.; Dal Canton, A. Cyclosporine induces different responses in human epithelial, endothelial and fibroblast cell cultures. Kidney Int. 2000, 58, 123-130. [CrossRef] [PubMed]

42. Jennings, P.; Koppelstaetter, C.; Aydin, S.; Abberger, T.; Wolf, A.M.; Mayer, G.; Pfaller, W. Cyclosporine A induces senescence in renal tubular epithelial cells. Am. J. Physiol. Renal Physiol. 2007, 293, F831-F838. [CrossRef] [PubMed]

43. Patschan, D.; Schwarze, K.; Tampe, B.; Zeisberg, M.; Patschan, S.; Müller, G.A. Endothelial Colony Forming Cells (ECFCs) in murine AKI-Implications for future cell-based therapies. BMC Nephrol. 2017, 18, 53. [CrossRef]

44. Critser, P.J.; Yoder, M.C. Endothelial colony-forming cell role in neoangiogenesis and tissue repair. Curr. Opin. Organ Transplant. 2010, 15, 68-72. [CrossRef] [PubMed]

45. Au, P.; Daheron, L.M.; Duda, D.G.; Cohen, K.S.; Tyrrell, J.A.; Lanning, R.M.; Fukumura, D.; Scadden, D.T.; Jain, R.K. Differential in vivo potential of endothelial progenitor cells from human umbilical cord blood and adult peripheral blood to form functional long-lasting vessels. Blood 2008, 111, 1302-1305. [CrossRef] [PubMed]

46. Keighron, C.; Lyons, C.J.; Creane, M.; O’Brien, T.; Liew, A. Recent Advances in Endothelial Progenitor Cells Toward Their Use in Clinical Translation. Front. Med. 2018, 5, 354. [CrossRef]

47. Sim, S.-L.; Alexis, J.; Roy, E.; Shafiee, A.; Khosrotehrani, K.; Patel, J. Immunosuppression Agent Cyclosporine Reduces SelfRenewal and Vessel Regeneration Potentiation of Human Endothelial Colony Forming Cells. Stem Cells Transl. Med. 2019, 8, 162-168. [CrossRef] [PubMed]

48. Eguchi, R.; Kubo, S.; Ohta, T.; Kunimasa, K.; Okada, M.; Tamaki, H.; Kaji, K.; Wakabayashi, I.; Fujimori, Y.; Ogawa, H. FK506 induces endothelial dysfunction through attenuation of Akt and ERK1/2 independently of calcineurin inhibition and the caspase pathway. Cell. Signal. 2013, 25, 1731-1738. [CrossRef]

49. Hernández, G.L.; Volpert, O.V.; Íñiguez, M.A.; Lorenzo, E.; Martínez-Martínez, S.; Grau, R.; Fresno, M.; Redondo, J.M. Selective Inhibition of Vascular Endothelial Growth Factor-Mediated Angiogenesis by Cyclosporin a: Roles of the Nuclear Factor of Activated T Cells and Cyclooxygenase 2. J. Exp. Med. 2001, 193, 607-620. [CrossRef]

50. Banai, S.; Shweiki, D.; Pinson, A.; Chandra, M.; Lazarovici, G.; Keshet, E. Upregulation of vascular endothelial growth factor expression induced by myocardial ischaemia: Implications for coronary angiogenesis. Cardiovasc. Res. 1994, 28, 1176-1179. [CrossRef] [PubMed]

51. Uccelli, A.; Wolff, T.; Valente, P.; Di Maggio, N.; Pellegrino, M.; Gürke, L.; Banfi, A.; Gianni-Barrera, R. Vascular endothelial growth factor biology for regenerative angiogenesis. Swiss Med. Wkly. 2019, 149, w20011. [CrossRef]

52. Rafiee, P.; Heidemann, J.; Ogawa, H.; Johnson, N.A.; Fisher, P.J.; Li, M.S.; Otterson, M.F.; Johnson, C.P.; Binion, D.G. Cyclosporin A differentially inhibits multiple steps in VEGF induced angiogenesis in human microvascular endothelial cells through altered intracellular signaling. Cell Commun. Signal. 2004, 2, 3. [CrossRef]

53. Ruiz, S.; Chandakkar, P.; Zhao, H.; Papoin, J.; Chatterjee, P.K.; Christen, E.; Metz, C.N.; Blanc, L.; Campagne, F.; Marambaud, P. Tacrolimus rescues the signaling and gene expression signature of endothelial ALK1 loss-of-function and improves HHT vascular pathology. Hum. Mol. Genet. 2017, 26, 4786-4798. [CrossRef]

54. Charo, I.F.; Taubman, M.B. Chemokines in the pathogenesis of vascular disease. Circ. Res. 2004, 95, 858-866. [CrossRef]

55. Libby, P.; Theroux, P. Pathophysiology of coronary artery disease. Circulation 2005, 111, 3481-3488. [CrossRef] [PubMed]

56. Winter, R.L.; Tian, Y.; Caldwell, F.J.; Seeto, W.J.; Koehler, J.W.; Pascoe, D.A.; Fan, S.; Gaillard, P.; Lipke, E.A.; Wooldridge, A.A. Cell engraftment, vascularization, and inflammation after treatment of equine distal limb wounds with endothelial colony forming cells encapsulated within hydrogel microspheres. BMC Vet. Res. 2020, 16, 43. [CrossRef]

57. Liao, J.K. Linking endothelial dysfunction with endothelial cell activation. J. Clin. Invest. 2013, 123, 540-541. [CrossRef] [PubMed]

58. Sprague, A.H.; Khalil, R.A. Inflammatory cytokines in vascular dysfunction and vascular disease. Biochem. Pharmacol. 2009, 78, 539-552. [CrossRef] [PubMed]

59. Harvey, A.; Montezano, A.C.; Touyz, R.M. Vascular biology of ageing-Implications in hypertension. J. Mol. Cell. Cardiol. 2015, 83, 112-121. [CrossRef]

60. Sun, Z. Aging, arterial stiffness, and hypertension. Hypertension 2015, 65, 252-256. [CrossRef]

61. Popa, C.; Netea, M.G.; van Riel, P.L.C.M.; van der Meer, J.W.M.; Stalenhoef, A.F.H. The role of TNF-alpha in chronic inflammatory conditions, intermediary metabolism, and cardiovascular risk. J. Lipid Res. 2007, 48, 751-762. [CrossRef]

62. Mena, H.A.; Lokajczyk, A.; Dizier, B.; Strier, S.E.; Voto, L.S.; Boisson-Vidal, C.; Schattner, M.; Negrotto, S. Acidic preconditioning improves the proangiogenic responses of endothelial colony forming cells. Angiogenesis 2014, 17, 867-879. [CrossRef]

63. Schröder-Heurich, B.; von Hardenberg, S.; Brodowski, L.; Kipke, B.; Meyer, N.; Borns, K.; von Kaisenberg, C.S.; Brinkmann, H.; Claus, P.; von Versen-Höynck, F. Vitamin D improves endothelial barrier integrity and counteracts inflammatory effects on endothelial progenitor cells. FASEB J. 2019, 33, 9142-9153. [CrossRef]

64. Deng, X.L.; Li, X.X.; Liu, X.Y.; Sun, L.; Liu, R. Comparative study on circulating endothelial progenitor cells in systemic lupus erythematosus patients at active stage. Rheumatol. Int. 2010, 30, 1429-1436. [CrossRef]

65. Zhang, C. The role of inflammatory cytokines in endothelial dysfunction. Basic Res. Cardiol. 2008, 103, 398-406. [CrossRef] [PubMed]

66. Bautista, L.E.; Vera, L.M.; Arenas, I.A.; Gamarra, G. Independent association between inflammatory markers (C-reactive protein, interleukin-6, and TNF-alpha) and essential hypertension. J. Hum. Hypertens. 2005, 19, 149-154. [CrossRef] 
67. Smykiewicz, P.; Segiet, A.; Keag, M.; Żera, T. Proinflammatory cytokines and ageing of the cardiovascular-renal system. Mech. Ageing Dev. 2018, 175, 35-45. [CrossRef]

68. Brodowski, L.; Schröder-Heurich, B.; Kipke, B.; Schmidt, C.; von Kaisenberg, C.S.; von Versen-Höynck, F. Low Ethanol Concentrations Promote Endothelial Progenitor Cell Capacity and Reparative Function. Cardiovasc. Ther. 2020, 2020, 4018478. [CrossRef] [PubMed]

69. Zhang, Y.; Ingram, D.A.; Murphy, M.P.; Saadatzadeh, M.R.; Mead, L.E.; Prater, D.N.; Rehman, J. Release of proinflammatory mediators and expression of proinflammatory adhesion molecules by endothelial progenitor cells. Am. J. Physiol. Heart Circ. Physiol. 2009, 296, H1675-H1682. [CrossRef]

70. D'audigier, C.; Cochain, C.; Rossi, E.; Guérin, C.L.; Bièche, I.; Blandinières, A.; Marsac, B.; Silvestre, J.-S.; Gaussem, P.; Smadja, D.M. Thrombin receptor PAR-1 activation on endothelial progenitor cells enhances chemotaxis-associated genes expression and leukocyte recruitment by a COX-2-dependent mechanism. Angiogenesis 2015, 18, 347-359. [CrossRef] [PubMed]

71. Lehle, K.; Schreml, S.; Kunz-Schughart, L.A.; Rupprecht, L.; Birnbaum, D.E.; Schmid, C.; Preuner, J.G. mTOR inhibitors and calcineurin inhibitors do not affect adhesion molecule expression of human macro- and microvascular endothelial cells. J. Vasc. Res. 2008, 45, 333-342. [CrossRef]

72. Sasakawa, T.; Sasakawa, Y.; Masunaga, T.; Fujitsu, T.; Hirayama, Y.; Ohkubo, Y.; Mutoh, S. FK506 suppresses E-selectin, ICAM-1 and VCAM-1 expression on vascular endothelial cells by inhibiting tumor necrosis factor alpha secretion from peripheral blood mononuclear cells. Cytokine 2005, 29, 67-71. [CrossRef] [PubMed]

73. Badiwala, M.V.; Guha, D.; Tumiati, L.; Joseph, J.; Ghashghai, A.; Ross, H.J.; Delgado, D.H.; Rao, V. Epidermal growth factor-like domain 7 is a novel inhibitor of neutrophil adhesion to coronary artery endothelial cells injured by calcineurin inhibition. Circulation 2011, 124, S197-S203. [CrossRef]

74. Kidokoro, K.; Satoh, M.; Nagasu, H.; Sakuta, T.; Kuwabara, A.; Yorimitsu, D.; Nishi, Y.; Tomita, N.; Sasaki, T.; Kashihara, N. Tacrolimus induces glomerular injury via endothelial dysfunction caused by reactive oxygen species and inflammatory change. Kidney Blood Press. Res. 2012, 35, 549-557. [CrossRef]

75. Riesinger, L.; Saemisch, M.; Nickmann, M.; Methe, H. CD34+ circulating cells display signs of immune activation in patients with acute coronary syndrome. Heart Vessels 2018, 33, 1559-1569. [CrossRef]

76. Csiszar, A.; Wang, M.; Lakatta, E.G.; Ungvari, Z. Inflammation and endothelial dysfunction during aging: Role of NF-kappaB. J. Appl. Physiol. 2008, 105, 1333-1341. [CrossRef]

77. Savoia, C.; Schiffrin, E.L. Inflammation in hypertension. Curr. Opin. Nephrol. Hypertens. 2006, 15, 152-158. [CrossRef]

78. Savoia, C.; Schiffrin, E.L. Vascular inflammation in hypertension and diabetes: Molecular mechanisms and therapeutic interventions. Clin. Sci. 2007, 112, 375-384. [CrossRef] [PubMed]

79. Zhou, M.-S.; Schulman, I.H.; Raij, L. Vascular inflammation, insulin resistance, and endothelial dysfunction in salt-sensitive hypertension: Role of nuclear factor kappa B activation. J. Hypertens. 2010, 28, 527-535. [CrossRef] [PubMed]

80. De Winther, M.P.J.; Kanters, E.; Kraal, G.; Hofker, M.H. Nuclear factor kappaB signaling in atherogenesis. Arterioscler. Thromb. Vasc. Biol. 2005, 25, 904-914. [CrossRef] [PubMed]

81. López-Franco, O.; Hernández-Vargas, P.; Ortiz-Muñoz, G.; Sanjuán, G.; Suzuki, Y.; Ortega, L.; Blanco, J.; Egido, J.; Gómez-Guerrero, C. Parthenolide modulates the NF-kappaB-mediated inflammatory responses in experimental atherosclerosis. Arterioscler. Thromb. Vasc. Biol. 2006, 26, 1864-1870. [CrossRef] [PubMed]

82. Gu, J.-W.; Tian, N.; Shparago, M.; Tan, W.; Bailey, A.P.; Manning, R.D. Renal NF-kappaB activation and TNF-alpha upregulation correlate with salt-sensitive hypertension in Dahl salt-sensitive rats. Am. J. Physiol. Regul. Integr. Comp. Physiol. 2006, 291, R1817-R1824. [CrossRef]

83. Cui, R.; Tieu, B.; Recinos, A.; Tilton, R.G.; Brasier, A.R. RhoA mediates angiotensin II-induced phospho-Ser536 nuclear factor kappaB/RelA subunit exchange on the interleukin-6 promoter in VSMCs. Circ. Res. 2006, 99, 723-730. [CrossRef]

84. Rodríguez-Iturbe, B.; Ferrebuz, A.; Vanegas, V.; Quiroz, Y.; Mezzano, S.; Vaziri, N.D. Early and sustained inhibition of nuclear factor-kappaB prevents hypertension in spontaneously hypertensive rats. J. Pharmacol. Exp. Ther. 2005, 315, 51-57. [CrossRef]

85. Elks, C.M.; Mariappan, N.; Haque, M.; Guggilam, A.; Majid, D.S.A.; Francis, J. Chronic NF-\{kappa\}B blockade reduces cytosolic and mitochondrial oxidative stress and attenuates renal injury and hypertension in SHR. Am. J. Physiol. Renal Physiol. 2009, 296, F298-F305. [CrossRef]

86. Taylor, F.; Huffman, M.D.; Macedo, A.F.; Moore, T.H.M.; Burke, M.; Smith, G.D.; Ward, K.; Ebrahim, S. Statins for the primary prevention of cardiovascular disease. Cochrane Database Syst. Rev. 2013, CD004816. [CrossRef]

87. Scandinavian Simvastatin Survival Study Group. Randomised trial of cholesterol lowering in 4444 patients with coronary heart disease: The Scandinavian Simvastatin Survival Study (4S). Lancet 1994, 344, 1383-1389.

88. Kwak, B.; Mulhaupt, F.; Myit, S.; Mach, F. Statins as a newly recognized type of immunomodulator. Nat. Med. 2000, 6, 1399-1402. [CrossRef] [PubMed]

89. Rosenson, R.S.; Tangney, C.C. Antiatherothrombotic properties of statins: Implications for cardiovascular event reduction. JAMA 1998, 279, 1643-1650. [CrossRef] [PubMed]

90. Hölschermann, H.; Schuster, D.; Parviz, B.; Haberbosch, W.; Tillmanns, H.; Muth, H. Statins prevent NF-kappaB transactivation independently of the IKK-pathway in human endothelial cells. Atherosclerosis 2006, 185, 240-245. [CrossRef] 
91. Lin, C.-P.; Huang, P.-H.; Lai, C.F.; Chen, J.-W.; Lin, S.-J.; Chen, J.-S. Simvastatin Attenuates Oxidative Stress, NF-кB Activation, and Artery Calcification in LDLR- / - Mice Fed with High Fat Diet via Down-regulation of Tumor Necrosis Factor- $\alpha$ and TNF Receptor 1. PLoS ONE 2015, 10, e0143686. [CrossRef] [PubMed]

92. Meyer, N.; Brodowski, L.; Richter, K.; von Kaisenberg, C.S.; Schröder-Heurich, B.; von Versen-Höynck, F. Pravastatin Promotes Endothelial Colony-Forming Cell Function, Angiogenic Signaling and Protein Expression In Vitro. J. Clin. Med. 2021, 10, 183. [CrossRef] [PubMed]

93. Grundmann, M.; Haidar, M.; Placzko, S.; Niendorf, R.; Darashchonak, N.; Hubel, C.A.; von Versen-Höynck, F. Vitamin D improves the angiogenic properties of endothelial progenitor cells. Am. J. Physiol. Cell Physiol. 2012, 303, C954-C962. [CrossRef]

94. Tiefenthaler, M.; Hofer, S.; Ebner, S.; Ivarsson, L.; Neyer, S.; Herold, M.; Mayer, G.; Fritsch, P.; Heufler, C. In vitro treatment of dendritic cells with tacrolimus: Impaired T-cell activation and IP-10 expression. Nephrol. Dial. Transplant 2004, 19, 553-560. [CrossRef] [PubMed]

95. Dusting, G.J.; Akita, K.; Hickey, H.; Smith, M.; Gurevich, V. Cyclosporin A and tacrolimus (FK506) suppress expression of inducible nitric oxide synthase in vitro by different mechanisms. Br. J. Pharmacol. 1999, 128, 337-344. [CrossRef] [PubMed]

96. Gui, J.; Rohrbach, A.; Borns, K.; Hillemanns, P.; Feng, L.; Hubel, C.A.; von Versen-Höynck, F. Vitamin D rescues dysfunction of fetal endothelial colony forming cells from individuals with gestational diabetes. Placenta 2015, 36, 410-418. [CrossRef] [PubMed]

97. Brodowski, L.; Burlakov, J.; Myerski, A.C.; von Kaisenberg, C.S.; Grundmann, M.; Hubel, C.A.; von Versen-Höynck, F. Vitamin D prevents endothelial progenitor cell dysfunction induced by sera from women with preeclampsia or conditioned media from hypoxic placenta. PLoS ONE 2014, 9, e98527. [CrossRef] [PubMed]

98. Von Versen-Höynck, F.; Brodowski, L.; Dechend, R.; Myerski, A.C.; Hubel, C.A. Vitamin D antagonizes negative effects of preeclampsia on fetal endothelial colony forming cell number and function. PLoS ONE 2014, 9, e98990. [CrossRef]

99. Bradford, M.M. A rapid and sensitive method for the quantitation of microgram quantities of protein utilizing the principle of protein-dye binding. Anal. Biochem. 1976, 72, 248-254. [CrossRef] 